\title{
MODELING OF SUSPENDED MATTER DISTRIBUTION IN MARINE COASTAL AREAS: 1. DESCRIPTION OF THE SM-MODEL
}

\author{
K.A. Podgornyi ${ }^{1}$, A.V. Leonov ${ }^{2}$ \\ ${ }^{1}$ Atlantic Research Institute of Fisheries and Oceanography \\ ul.Dm.Donskoy,5. Kaliningrad, 236000,Russia, e-mail:kapborok@mail.ru \\ ${ }^{2}$ Shirshov Institute of Oceanology, Russian Academy of Sciences, 36, \\ Nakhimovskyi prospect, Moscow, 117997, Russia, e-mail: leonov@ocean.ru \\ Submitted 05.09.2017, accepted 25.12.2017
}

\begin{abstract}
A methodology is considered for developing a mathematical model to study the distribution of suspended matter concrentrations in coastal marine areas. This model assesses the consequences of dredging (namely the disturbance of the natural state of marine environment for bioresources), it reproduces the formation of suspended matter and its subsequent transport in the aquatic environment in shallow sea bays and offshore water areas. This problem is solved in two basic stages: at the first stage - the system of equations of hydrodynamics (the equations of the theory of "shallow water") is numerically integrated and the values of the mean components of the flow velocity are determined; and at the second stage - the system of turbulent diffusion equations is integrated, the processes of sedimentation of suspended matter, resuspension of bottom sediments, arrival of suspended matter from distributed point sources, their redistribution in the aquatic environment and the accumulation of residual quantities on the bottom are taken into account.
\end{abstract}

Keywords: equations of the theory of «the shallow water»; the system of advection and turbulent diffusion equations; initial and boundary conditions

\section{Introduction}

The spread of suspended matter (SM) in the coastal marine shallow water areas, bays and estuaries of rivers under natural conditions, as well as in the performance of various works in which an external mechanical action (for example, bypassing ${ }^{1}$ ) on bottom sediments is assumed, is a complex, multiscale and a multidimensional process. In the mixing zones of river and sea waters in river mouths, there are so-called "marginal filters" (Lisitsyn, 1994) in which important ecosystem processes occur (differential deposition of particles of different size composition, flocculation and

\footnotetext{
${ }^{1}$ Baypassing - a set of works with the purpose of mining building materials as well as restoration / creation of natural or artificial beaches. In particular, bypassing is carried out the excavation of soil and the mechanical movement of deposits from one section of the marine area to another.
} 
coagulation dissolved substances and SM, bioassimilation and biofiltration). The rates of chemical transformations of various components in the aquatic environment, including the rates of biochemical transformation of biogenic substances (BS) in such zones are much higher than in the open sea. Biological processes include an activity of living organism community (from bacteria to zooplankton), and in a number of cases the role of macrophytes is important. Next processes are carried out at the expense of biological processes: the transformation of dissolved substances and SM, in particular, BS; transfer of dissolved substances into SM; biofiltration or extraction of SM from water and transferring it to a bottom sediment. Thus, marine coastal shallow water areas, bays and mouths of rivers are functioning as unique systems, similar to the "chemical and biochemical reactors" (Lisitsyn, 1994) under relatively shallow depths and low temperatures. Dissolved organic matter (DOM) and SM in natural waters play a key role in various natural processes in the marine environment.

Their role is especialy great in shallow water areas and shelf areas where concentrations of DOM and SM can be significant. For example, in the Baltic Sea, DOM concentrations are typically 3-4 times higher than in the oceans (Maciejewska, Pempkowiak, 2014, 2015). In the waters of shallow lagoons, the content of SM is usually even higher and significantly affects the speed and direction of performed processes in these ecosystems.

Unfortunately, the processes of SM propagation are mainly studied from the point of view of hydrology, morphology, and hydrodynamics (Lisitsyn, Barenblatt, 1983), while the SM as itself is often considered as a "passive admixture" or a tracer in the modeling (Rukhovets, 1982; Ryabchenko et al., 2006; Ryanzhin et al., 1984; Molchanov et al., 2010). This approach is acceptable in solving local problems for the studying the spatio-temporal dynamics of SM that enter to the aquatic environment, for example, as a result of landfill, dredging, pipelines, bank protection measures, volley discharges from sewage treatment plants or in emergency situations. However, with a more complex task in the comprehensive study of the SM and DOM transformation processes in natural waters, in order to solve it, in addition to direct observations and laboratory experiments, the different mathematical models of aquatic ecosystems, and in particular simulation models, are necessary for the usage. There are examples of the construction and practical application of similar models (Leonov, 2008; Podgornyii, Leonov, 2013a, b).

In modern conditions, the entire complex of problems of the SM formation and distribution are especially relevant and are obligated for the consideration for the ecological justification of all projects without exception, within which any impacts on the aquatic environment are carried out and the conditions of living of aquatic biological resources are violated. Without simulation modelling it is impossible to answer on the questions related to the state of the marine environment and damage for water biological 
resources when drawing up an expert opinion on the assessment of the effect for environmental protection (AEEP) for a specific project. When solving the practical problem of modeling the SM propagation in the water environment, the system of equations of hydrodynamics (two- or three-dimensional) and the system of equations of turbulent diffusion are numerically integrated with taking into account of the different processes and the different scales of turbulent exchange determined by parameters of the SM mixing for different instants of time; SM sedimentation and resuspension of bottom sediments; and in a number of cases, the conditions for the cohesion of SM particles are estimated at the water-bottom sediment interface; and also the jet effects including an important process of accelerated initial immersion of a "heavy" jet (or volley drop of soil); and the effect of flocculation associated with the cohesion of SM particles with its subsequent rapid deposition; and the arrival of SM into water from distributed (point) sources. In the winter period, it is necessary to take into account the formation and/or the presence of the ice cover (within the entire water area or on its part). In a number of cases, one should take into account the effect of density stratification of the water.

The mathematical model for investigating and forecasting the SM distribution in marine coastal areas should take into account not only the above processes and conditions, but also other important phenomena (Arkhipov et al., 2004): the multidispersity of $\mathrm{SM}$ and/or differences in the granulometric composition of suspensions polluting the water area (this leads to differential precipitation of different SM fractions); the turbulent nature of the SM transport in the considered design area and, as a consequence, the need to take into account the dependence of the horizontal diffusion coefficients on the linear size of the contamination zone; and space-time variability of the velocity and flow direction fields; and spatial inhomogeneities of the flow velocity field within the water area; and possible long-term (from several days to several months) nature of engineering works; and the possibility of continuous (or episodic) movement of the SM source in the water area during the work.

Thus, the mathematical model should use an information on the hydrometeorological and hydrological features of the work area and modern ideas about the physicochemical and biological processes that determine the SM formation and distribution in the water environment; and also the technical characteristics of equipments applying of which leads to the SM appearance in the coastal zone of the sea, and a specific technological scheme of dredging and other required works.

The problem of modeling the space-time dynamics of flow fields considers the case when the horizontal dimensions of the water body are much greater than its depth; and there is no pronounced seasonal thermocline in the water body and there is a relative vertical homogeneity (or single-layer structure) of currents. In this case, the applying the approximations of the theory of "the shallow water" (or the Saint-Venant 
system of equations) is permissible. Models of thermo-hydrodynamic processes are quite common in which these or other variants of system equations of the shallow water are used (for example, models of water circulation in shallow lakes, reservoirs, bays and seas, sediment dynamics model, and conditions of bottom sediment accumulation, distribution of conservative and non-conservative impurities in watercourses, shallow lakes and sea bays).

Despite a number of simplifications, the mathematical models and numerical methods for calculating currents in shallow-water continental water bodies (lakes, reservoirs, sea bays) and coastal marine areas remain quite complex. The hydrodynamic problems of the theory of shallow water are formulated in the form of initial-boundary value tasks. At the same time, the necessary information (morphometric data, impact functions, initial state of the process and conditions at the boundaries) should be set fairly accurately in the space-time region where the motion of the water mass is considered. It is also required to propose an economical numerical method for solving a system of equations that are nonlinear in their structure. The totality of all characteristics ensures the quality of the mathematical model.

\section{The system of equations according theory of the shallow water}

It is represented by the Saint-Venant system of equations:

$$
\begin{gathered}
U=\frac{1}{h+\varsigma} \int_{-h}^{\varsigma} u d z, \mathrm{~V}=\frac{1}{\mathrm{~h}+\varsigma} \int_{-h}^{\varsigma} v d z \\
H=h+\varsigma \\
\frac{\partial U}{\partial t}+U \frac{\partial U}{\partial x}+V \frac{\partial U}{\partial y}-K_{T}\left(\frac{\partial^{2} U}{\partial x^{2}}+\frac{\partial^{2} U}{\partial y^{2}}\right)+g \frac{\partial \varsigma}{\partial x}-f V+g \frac{U \sqrt{U^{2}+V^{2}}}{C^{2} H}-\frac{1}{\rho_{w} H} \tau_{x}^{s}=0 \\
\frac{\partial V}{\partial t}+U \frac{\partial V}{\partial x}+V \frac{\partial V}{\partial y}-K_{T}\left(\frac{\partial^{2} V}{\partial x^{2}}+\frac{\partial^{2} V}{\partial y^{2}}\right)+g \frac{\partial \varsigma}{\partial y}+f U+g \frac{V \sqrt{U^{2}+V^{2}}}{C^{2} H}-\frac{1}{\rho_{w} H} \tau_{y}^{s}=0, \\
\frac{\partial \varsigma}{\partial t}+\frac{\partial(H U)}{\partial x}+\frac{\partial(H V)}{\partial y}=0
\end{gathered}
$$

where $U, V$ are the vector projections of the average velocity along the coordinate axis (the axis $O X$ is directed to the east, $O Y$ - to the north, $O Z$ - upward); $\varsigma$ - elevation of the free surface above the reference level surface; $h$ is the distance from the reference level surface to the bottom; $H$ is the total depth of the water body at a given time; $K_{T}-$ coefficient of horizontal turbulent exchange; $f$-Coriolis parameter; $g$ - acceleration of gravity; $\boldsymbol{\tau}_{x}^{s}, \boldsymbol{\tau}_{y}^{s}$ - the projection of the tangential wind stress on the coordinate axis; $\rho_{w}$ - density of water; $C$ is the Chezy coefficient. 
In accordance with the Van Dorn law, at the developed turbulence of the flow, the following relationships are taken to calculate the components of the tangential wind stress:

$$
\tau_{x}^{s}=\theta \rho_{a} W_{a}^{2} \cos \alpha_{w}, \tau_{y}^{s}=\theta \rho_{a} W_{a}^{2} \sin \alpha_{w},
$$

where $W_{a}$ - wind speed over the water body, $\alpha_{w}-$ wind direction, $\rho_{a}-$ air density, $\theta-$ coefficient of hydraulic resistance on the water surface. The coefficient of Chezy, $C$, takes into account the loss of energy to overcome frictional forces depending on the degree of roughness and depth of the water body. It is calculated using semi-empirical formulas. In particular, the Manning and Pavlovsky formulas are widely used:

$$
\begin{aligned}
& C=\frac{1}{n_{r}} \sqrt[6]{R}, \\
& C=\frac{1}{n_{r}} R^{\sigma},
\end{aligned}
$$

where $n_{r}$ - coefficient of roughness determined by special tables or calculated by the empirical ratio, depending on the average height of the roughness protrusions $\xi$ : $n_{r}=\frac{0.13}{\sqrt{g}} \sqrt[6]{\xi} ; R$ is the hydraulic radius (in practice, $R$ is the total depth of flow $H$ ). The exponent in formula (1.8) is calculated from the empirical relationship that establishes a relationship between $\sigma$ oт $n_{r}$ and $R$ :

$$
\sigma=2.5 \sqrt{n_{r}}-0.75 \sqrt{R}\left(n_{r}-0.10\right)-0.13 \text {. }
$$

We supplement the system (1.3)-(1.5) with the following boundary conditions:

1) the noflow condition is fixed on the solid contour of the computational domain (or the normal component of the average velocity of the flow is equal to zero: $\vec{U}_{n_{b}}=0$ ); and

2) the radiation condition is used on the liquid boundary of the computational domain:

$$
\vec{U}_{n_{b}}=\varsigma \sqrt{\frac{g}{H}} \text {, если } \vec{U}_{n_{b}} \geq 0 \text { and }\left\{\begin{array}{l}
\vec{U}_{n_{b}}=\varsigma \sqrt{\frac{g}{H}}, \text { if } \vec{U}_{n_{b}} \leq 0, \\
\vec{U}_{\tau_{b}}=0,
\end{array}\right.
$$

where $\vec{U}_{\tau_{b}}$ is the tangential component of the average velocity along the depth of the flow at the liquid boundary of the calculated region. In the confluence of rivers (if any), the energy condition is used: $U_{n}^{2}+g \varsigma=\frac{Q_{\text {river }}^{2}}{W_{\text {river }}^{2} h_{\text {river }}^{2}}$ (where $Q_{\text {river }}-$ flow rate; $W_{\text {river }}$, $h_{\text {river }}$ - respectively the width and the average depth in the alignment of the river). 
As initial conditions, zero velocity and level values (rest state) will be used. When the wind changes over the water body, the initial fields are the values of the flow and elevation velocities obtained at the previous time step.

For the numerical solution of the modified Saint-Venant system of equations, an implicit spatially and time-separated difference scheme is used with the applying the alternating direction method (Podgornyii, 2003) (realized with the aid of the $C$-grid of Arakawa). For the stability of the computational process, the system of equations (1.1) (1.5) is modified near the boundary so that the differential operator for the advective terms on the boundary is the differentiation operator in the direction tangential to the boundary (Baklanovskaya et al., 1979). Modified equations are approximated on the selected spaced grid by difference equations that can be solved by the sweep method.

The time step $\tau$ for solving the equations depends on the grid steps $(\Delta s)_{x},(\Delta s)_{y}$ on the spatial coordinates. When choosing $\tau$, it is necessary to ensure that the criterion for stability of computations is satisfied on the basis of the Courant-Friedrichs-Levy criterion (CFL): $\left(\frac{\tau}{(\Delta s)_{x, y}^{\max }}\right) \sqrt{g H}<1$, or $\tau<\frac{(\Delta s)_{x, y}^{\max }}{\sqrt{g H}}$, where $(\Delta s)_{x, y}^{\max }-$ is the largest step of the grid with respect to spatial coordinates.

To parameterize the coefficient of horizontal turbulent exchange $K_{T}$, different approaches are used, and in the simplest case, its constant value is used (Chubarenko, Tchepikova, 2001). To guarantee the computational stability, it is necessary to take into account its dependence on the grid steps $(\Delta s)_{x},(\Delta s)_{y}$ on the spatial coordinates $(O X$ and $O Y$, respectively), and also on the time step (estimated by the criterion of CFL). In calculations, the specific value of the coefficient $K_{T}$ is found from the relationship: $K_{T}=0.02(\Delta s)_{x}(\Delta s)_{y} / \tau$ (MIKE 21..., 2012). In a number of models (Klevanny, Smirnova, 2009; Matishov et al., 2009; Klevanny et al., 2001) at the construction of numerical schemes for estimating the coefficient of horizontal turbulent exchange, the Smagorinsky parametrization (Smagorinsky, 1963) is used. It is this parametrization that will be used to calculate the coefficient values $K_{T}$ and to estimate the coefficient of horizontal turbulent diffusion (equation (2.39)). To date, other approaches for calculations have been widely used (Fahmy et al., 2013; Lai, 2010; MIKE 21.., 2012) - for the parametric closure of the system of equations (1.1)-(1.5), turbulent exchange models are used (most often, $k-\varepsilon$ - models of turbulent exchange (Cebeci, 2004; Rodi, 1980). The application of other approaches and models of turbulence as well as their effective practical numerical realization are considered in (Cebeci, 2004). 


\section{System of equations for processes of advection and turbulent diffusion}

In a general form, the system of equations for describing advection and turbulent diffusion takes into account sedimentation of SM, resuspension of bottom sediments as well as the receipt of SM with different granulometric composition from distributed (point) sources, connected with engineering works on a particular site. When using convective terms in a non-divergent (characteristic) form, this system of equations can be represented as follows:

$$
\begin{gathered}
\partial\left(C_{n}\right)_{\text {sed }}^{W} / \partial t+U \partial\left(C_{n}\right)_{\text {sed }}^{W} / \partial x+V \partial\left(C_{n}\right)_{\text {sed }}^{W} / \partial y+\left(W_{s}\right)_{n} \partial\left(C_{n}\right)_{\text {sed }}^{W} / \partial z= \\
=\left(A_{\eta}\right)_{n} \Delta_{\eta}\left(C_{n}\right)_{\text {sed }}^{W}+F_{n}\left(t,\left(C_{1}\right)_{\text {sed }}^{W}, \ldots,\left(C_{n}\right)_{\text {sed }}^{W}\right), n=\overline{1, N} .
\end{gathered}
$$

here: $\left(C_{n}\right)_{\text {sed }}^{W}$ - the values of SM concentrations in water for the size fraction $n$ (in the future, instead of the designation $\left(C_{n}\right)_{\text {sed }}^{W}$, we will use its brief notation $\left.C_{n}\right) ; U, V$ are the projections of the vector of the average velocity along the axis of coordinates $O X$ and $O Y$, respectively, the axis $O X$ is directed to the east, the axis $O Y$ - to the north; $\left(W_{s}\right)_{n}$ - rates of gravitational settling of SM (sedimentation rate of each size fraction of $\mathrm{SM})$ in the flow, taking into account the difference in sedimentation rates of SM in the flow compared to standing water; $O Z$ - vertical coordinate, directed downwards; $\left(A_{\eta}\right)_{n}-$ coefficient of horizontal turbulent diffusion for the size fraction $n ; \Delta_{\eta}-$ twodimensional Laplace operator; $F_{n} \equiv \operatorname{Rate}\left(C_{n}\right)$ - a functional operator used to calculate the rate of change in the concentration of a given fraction of SM; $N$ is the total number of size fractions; $t$ is time.

The formulation of boundary and initial conditions depends on the hydrological features of a particular water body, the research tasks and the availability of observational data. In particular, the boundary conditions can be as follows:

- on the entire solid boundary, in the outflows of the outflowing rivers (if any) and at the open border with the direction of water movement beyond the calculation area, the condition that the derivative in the direction of the external normal to the boundary of the water body is zero:

$$
\partial C_{n} / \partial \boldsymbol{n}_{b}=0 .
$$

- on the open border with the direction of movement of water inside the calculation area, the first boundary condition is set - specific values of the concentrations of individual SM fractions on this border are specified;

- in the areas of inflowing rivers (if any), the condition is given

$$
\partial C_{n} / \partial \boldsymbol{n}_{b}-\boldsymbol{V}_{n}\left(C_{n}-C_{n_{-} \text {river }}\right)=0 \text {, }
$$


where $V_{n}$ is the projection of the water flow velocity on the outer normal to the boundary, $C_{n_{-} \text {river }}$ is the concentration of SM components in the aqueous medium (for each size fraction $n$ ).

It follows from equation (2.1) that the evolution of SM fields (of a particular fraction $n$ ) is determined by the advective transfer of SM along the trajectories of the particles, the gravitational sedimentation of SM, turbulent diffusion, sedimentation of $\mathrm{SM}$, and the resuspension of bottom sediments depending on the conditions of hydrodynamics (the structure of the flow field and the effect of water waves).

In the scheme of numerical integration of the system of equations (2.1), the method of splitting by physical processes and spatial coordinates is used (Marchuk, 1988; Marchuk et al., 1987; Podgornyii, 2003; Samarskii, Vabishchevich, 1999a, b). The general splitting scheme includes four stages of integration of the system (2.1). In the first stage, the advective transfer equations for each of the isolated SM fractions along the particle trajectories are solved on the time interval:

$$
\partial C_{n} / \partial t+U \partial C_{n} / \partial x+V \partial C_{n} / \partial y=0, n=\overline{1, N}
$$

with the initial conditions $C_{n}^{k+1 / 4}\left(t_{k}\right)=C_{n}^{k}$.

At the second stage, the equations describing the processes of gravitational deposition of SM are solved in the same time interval:

$$
\partial C_{n} / \partial t+\left(W_{s}\right)_{n} \partial C_{n} / \partial z=0, n=\overline{1, N}
$$

with the initial conditions $C_{n_{-} P M}^{k+2 / 4}\left(t_{k}\right)=C_{n_{-} P M}^{k+1 / 4}\left(t_{k}+\tau\right)$.

In the third stage, the equations of turbulent exchange of SM for each fraction $n$ are solved in the same time interval:

$$
\partial C_{n} / \partial t=\left(A_{\eta}\right)_{n} \Delta_{\eta}\left(C_{n}\right), n=\overline{1, N}
$$

with the initial condition $C_{n}^{k+3 / 4}\left(t_{k}\right)=C_{n}^{k+2 / 4}\left(t_{k}+\tau\right)$.

At the last (fourth) stage, for each selected fraction $n$, the system of equations is solved that describes the local processes of sedimentation of SM and resuspension of bottom sediments as well as the receipt of SM from point sources:

$$
\partial C_{n} / \partial t=F_{n}\left(t, C_{1}, \ldots, C_{n}\right), n=\overline{1, N}
$$

with the initial condition $C_{n}^{k+1}\left(t_{k}\right)=C_{n}^{k+3 / 4}\left(t_{k}+\tau\right)$.

To integrate the system of equations (2.7) which for each integer node of the grid region describes the processes of deposition of SM (for each of the $n$ isolated fractions), the perturbation of the bottom sediments and the incoming of SM from distributed point sources, the Runge-Kutta-4 method is used in the Gill modification. In accordance with the accepted sequence of splitting of the initial problem, at the last stage at each inner 
point of the grid region, a system of equations is solved that describes the local processes of changing the SM concentrations in water environment:

$$
\partial C_{n} / \partial t=F_{n}\left(t, C_{1}, \ldots, C_{n}\right),(n=\overline{1, N})
$$

with the initial condition $C_{n}^{k+1}\left(t_{k}\right)=C_{n}^{k+3 / 4}\left(t_{k}+\tau\right)$. Values $C_{n}(n=\overline{1, N})$ at this point are stored in the two-dimensional array $Y_{n, m}(n=\overline{1, N}, m=\overline{0,4})$ in which the initial conditions are written in the form of the equation: $Y_{n, 0}=C_{n}^{k+3 / 4}\left(t_{k}+\tau\right)(\mathrm{n}=\overline{1, \mathrm{~N}})$

An auxiliary two-dimensional array is also used, $Q_{n, m}(n=\overline{1, N}, m=\overline{0,4})$, in which zero initial values are given: $Q_{n, 0}=0(n=\overline{1, N}), t_{0}=t_{k}$. At the beginning of the calculation, a special set of coefficients is determined by this method: $A_{1}=0,5$, $A_{2}=1-\sqrt{0,5}, A_{3}=1+\sqrt{0,5}, A_{4}=1 / 6, B_{1}=2,0, B_{2}=1, B_{3}=1, B_{4}=2,0, C_{1}=0,5$, $C_{2}=1-\sqrt{0,5}, C_{3}=1+\sqrt{0,5}, C_{4}=1 / 2$. Gill's procedure begins with setting the index $m=1$. Next, value $K_{n, m}=F_{n}\left(t_{m-1}, C_{1, m-1}, \ldots, C_{n, m-1}\right)(n=\overline{1, N})$ are calculated, as well as values:

$$
\begin{gathered}
Y_{n, m}=Y_{n, m-1}+\left(A_{m}\left(\tau K_{n, m}-B_{m} Q_{n, m-1}\right)\right), \\
Q_{n, m}=Q_{n, m-1}+3\left(A_{m}\left(\tau K_{n, m}-B_{m} Q_{n, m-1}\right)\right)-C_{m} \tau K_{n, m}(n=\overline{1, N}) .
\end{gathered}
$$

This procedure is repeated successively for values $m=2,3,4$, starting with the step $K_{n, m}$. As the calculations are performed, $t_{\mathrm{m}}$ values change in the following way: $t_{1}=t_{0}+\tau / 2=t_{k}+\tau / 2, t_{2}=t_{0}+\tau / 2=t_{k}+\tau / 2, t_{3}=t_{0}+\tau=t_{k}+\tau$. At the end of this process, consisting of four steps, the values $C_{n}\left(t_{k}+\tau\right)(\mathrm{n}=\overline{1, \mathrm{~N}})$ will turn out to be $Y_{n, 4}(n=\overline{1, N})$.

Calculation of the rate of change in the SM concentrations in water due to the processes of SM sedimentation, stirring up the bottom sediments and incoming of SM into water from distributed point sources at each step $\tau$ in time is carried out in the model according to the following general formula:

$$
\begin{gathered}
\operatorname{Rate}\left(C_{n}\right)=-f_{\text {sed }}\left(U^{\text {curr }} ; U^{\text {wave }}\right)_{\left(C_{n}\right)_{\text {sed }}^{W}}+f_{\text {ReSusp }}\left(U^{\text {curr }} ; U^{\text {wave }}\right)_{\left(C_{n}\right)_{\text {sed }}^{B}}+ \\
+v_{\text {PointSource }}{ }_{\left(C_{n}\right)} \text { Ped }_{\text {sed }}^{\text {pource }} \\
\end{gathered}
$$

where $\left(C_{n}\right)_{\text {sed }}^{W}$ - current values of the SM concentrations in water for each size fraction $n ;\left(C_{n}\right)_{\text {sed }}^{B}$ - current values of SM concentrations in the bottom sediment; $\left(C_{n}\right)_{\text {sed }}^{\text {Pointsource }}$ values of SM concentrations incoming from distributed point sources; $v_{\text {Pointsource }}-$ velocity of intake of SM from point sources. Changes in SM concentrations in water for each $n$-th isolated fraction depend on the flow velocity and the characteristics of water 
waves. This dependence is taken into account in the model by introducing terms $-f_{\text {sed }}\left(U^{\text {curr }} ; U^{\text {wave }}\right)_{\left(C_{n}\right)_{\text {sed }}^{W}}$ and $f_{\text {ReSusp }}\left(U^{\text {curr }} ; U^{\text {wave }}\right)_{\left(C_{n}\right)_{\text {sed }}^{B}}$ in formula (2.9), which describe the corresponding processes of SM sedimentation and resuspension of the bottom sediment. The arguments of the functions $f_{\text {sed }}\left(U^{\text {curr }} ; U^{\text {wave }}\right)$ and $f_{\text {ReSusp }}\left(U^{\text {curr }} ; U^{\text {wave }}\right)$ are the values of $U^{\text {curr }}$ and $U^{\text {wave }}$ These values are the average vertical velocity of water flow and the rate of variable flow initiated by water waves.

The velocities of the processes of SM sedimentation and the bottom sediment resuspension depend on $\tau_{\text {bottom }}$ - the tangential stress at the bottom (calculated by $U^{\text {curr }}$ and $\left.U^{\text {wave }}\right)$. Write the functions $f_{\text {sed }}\left(U^{\text {curr }} ; U^{\text {wave }}\right)$ and $f_{\text {ReSusp }}\left(U^{\text {curr }} ; U^{\text {wave }}\right)$ in a general form (Marchuk, 1988; Marchuk et al., 1987; Podgornyi, 2003; Samarskii, Vabishchevich, 1999a, b):

$$
\begin{gathered}
f_{\text {sed }}\left(U^{\text {curr }} ; U^{\text {wave }}\right)= \begin{cases}\left(W_{s}\right)_{n}=0, & \tau_{\text {bottom }} \geq \tau_{C_{n}}^{\text {crit_sed }}, \\
\left(W_{s}\right)_{n}=U_{C_{n}}^{\text {sed }} \cdot\left(1.0-\frac{\tau_{\text {bottom }}}{\tau_{C_{n}}^{\text {crit_sed }}}\right), & \tau_{\text {bottom }}<\tau_{C_{n}}^{\text {crit_sed }} ;\end{cases} \\
f_{\text {Resusp }}\left(U^{\text {curr }} ; U^{\text {wave }}\right)= \begin{cases}0, & \tau_{\text {bottom }} \leq \tau_{C_{n}}^{\text {crit_resusp }}, \\
U_{C_{n}}^{\text {resusp }} \cdot\left(\frac{\tau_{\text {bottom }}}{\tau_{C_{n}}^{\text {crit_resusp }}}-1.0\right), \tau_{\text {bottom }}>\tau_{C_{n}}^{\text {crit_resusp }},\end{cases}
\end{gathered}
$$

where $U_{C_{n}}^{\text {sed }}, U_{C_{n}}^{\text {resusp }}$ are the rate of SM sedimentation and stirring respectively for a given layer of water $(n=\overline{1, N}) ; \tau_{C_{n}}^{\text {crit sed }}$ and $\tau_{C_{n}}^{\text {crit_resusp }}$ - the critical values of the tangential stress at the bottom, which determine the beginning of the SM sedimentation $(n=\overline{1, N})$ and the stirring up of the sediments $(n=\overline{1, N})$, respectively.

It follows from formulas (2.10) and (2.11) that the corresponding sedimentation rates of a given SM fraction are a function of the ratio $\frac{\tau_{\text {bottom }}}{\tau_{C_{n}}^{\text {crit sed }}}(n=\overline{1, N})$, and the disturbances of the bottom sediments are a function of the ratio $\frac{\tau_{\text {bottom }}}{\tau_{C_{n}}^{\text {crit }} \text { resusp }}(n=\overline{1, N})$. Depending on the ratio $\tau_{\text {bottom }}$ and critical values of the tangential stresses on the bottom, for the $n$-th fraction of SM, either SM sedimentation or stirring up of the bottom sediments may predominate.

Tangential stress $\tau_{\text {bottom }}$ is calculated as a sum of stresses caused by the effects of water flow and wind waves on the bottom of the water body (Chao et al., 2008; Davies, Lawrence, 1994; Hipsey et al., 2006; Signell et al., 1990; Teeter et al., 2001):

$$
\tau_{\text {bottom }}=\tau_{\text {bottom }}^{\text {curr }}+\tau_{\text {bottom }}^{\text {wave }} \text {. }
$$


For calculation $\tau_{\text {bottom }}$, there are more complex nonlinear models (Glenn, Grant, 1987; Grant, Madsen, 1979; Stanev et al., 2009). In general, the tangential stress at the bottom is determined by the dynamic velocity $u_{*}$, due to both the water flow and waves:

$$
\tau_{\text {bottom }}=\rho_{w} u_{*}^{2},
$$

where $\rho_{w}$ is the density of water. Taking into account (2.12), equation (2.13) looks like this:

$$
\tau_{\text {bottom }}=\rho_{w} \cdot\left(\left(u_{*}^{\text {curr }}\right)^{2}+\left(u_{*}^{\text {wave }}\right)^{2}\right)
$$

In equation (2.14), $u_{*}^{\text {curr }}$ and $u_{*}^{\text {wave }}$ are the dynamic values of the velocity, due respectively to the water flow and wind waves.

Next, the density of sea water $\rho_{w}\left(T_{w}, S\right)$ (in $\left.\mathrm{kg} / \mathrm{m}^{3}\right)$ is calculated for its salinity $S$ (in \%o) and temperature $T_{W}\left(\right.$ in $\left.{ }^{\circ} \mathrm{C}\right)$ :

$$
\begin{gathered}
\rho_{w}\left(T_{w}, S\right)=\rho_{w}\left(T_{w}, 0\right)+S\left(0.824439-4.0899 \cdot 10^{-3} T_{w}+7.6438 \cdot 10^{-5} T_{w}^{2}-\right. \\
\left.-8.2467 \cdot 10^{-7} T_{w}^{3}+5.3875 \cdot 10^{-9} T_{w}^{4}\right)+ \\
+S^{3 / 2}\left(-5.72466 \cdot 10^{-3}+1.0227 \cdot 10^{-4} T_{w}-1.6546 \cdot 10^{-6} T_{w}^{2}\right)+4.8314 \cdot 10^{-4} S^{2} .
\end{gathered}
$$

The formula (2.15) is applicable for the range $S(0-42 \%)$, and $T_{w}$ - for the freezing temperature of seawater (from $S>0 \%$ ) to $40{ }^{\circ} \mathrm{C}$. The value $T_{w f},{ }^{\circ} \mathrm{C}$, for the range $S(1-$ $40 \%$ ) is calculated by the equation (Kester, 1974):

$$
T_{w f}=-0.0137-5.1990 \cdot 10^{-2} S-7.225 \cdot 10^{-5} S^{2} .
$$

For the parametrization $\tau_{\text {bottom }}^{\text {curr }}$ according to the "hard wall law" of Karman-Prandtl, we assume that $\left(u_{*}^{\text {curr }}\right)^{2} \sim\left(U^{\text {curr }}\right)^{2}$. Taking this assumption into account, we write down that

$$
\tau_{\text {bottom }}^{\text {curr }}=\rho_{w} C_{D}\left(U^{\text {curr }}\right)^{2},
$$

where $C_{D}$ is the coefficient of resistance. When using a two-dimensional version of the hydrodynamic module, $U^{\text {curr }}$ is considered as the average vertical velocity of water displacement. In this case the value $C_{D}$ is calculated using the relation:

$$
C_{D}=0.16\left(1+\ln \left(\frac{Z_{0}}{Z_{W}}\right)\right)^{-2},
$$

where $Z_{0}$ is some average scale height of the protuberances of the bottom roughness; $Z_{w}$ is the depth of water at the point of calculation. The average scale height $Z_{0}$ of the bottom roughness is determined by the formula $Z_{0}=D_{50} / 12$, where $D_{50}$ is the weighted average particle size dependent on the percentage contribution of particles of 


\section{K.A. Podgornyi, A.V. Leonov}

different type and particle size in the sediment layer in the water body (Stanev et al., 2009).

In shallow-water lakes, bays and lagoons, the shear stress $\tau_{\text {bottom }}^{\text {wave }}$ under the action of wind waves on the bottom of the water body is calculated on the basis of the linear theory of wave processes, and $\tau_{\text {bottom }}^{\text {wave }}$ is assumed to be proportional to the square of the maximum wave orbital velocity near the bottom (Jonsson, 1966; Luettich et al., 1990):

$$
\tau_{\text {bottom }}^{\text {wave }}=\frac{1}{2} \rho_{w} f_{\text {wave }}\left(U_{\text {wave }}^{\max }\right)^{2},
$$

where $f_{\text {wave }}$ is the coefficient of wave friction. For shallow water and linear wave theory, the speed $U_{\text {wave }}$ of the orbital wave motion is calculated from the equation (Shore protection..., 1984):

$$
U_{\text {wave }}=\frac{\pi H_{\text {wave }}}{T_{\text {wave }} \operatorname{sh}\left(k Z_{w}\right)} \cos (k x-\omega t),
$$

where $H_{\text {wave }}, T_{\text {wave }}$ are the height and period of the wave respectively; $k=\frac{2 \pi}{L_{\text {wave }}}-$ wave number, $L_{\text {wave }}$ - wavelength; $\omega=\frac{2 \pi}{T_{\text {wave }}}-$ angular frequency. The maximum value $U_{\text {wave }}^{\max }$ of the speed of the orbital wave motion is achieved when $\cos (k x-\omega t)=1$ or provided that $k x-\omega t=0$. Then from equation (2.20) we obtain that

$$
U_{\text {wave }}^{\max }=\frac{\pi H_{\text {wave }}}{T_{\text {wave }} \operatorname{sh}\left(k Z_{\mathrm{w}}\right)} .
$$

The final expression for the calculation of $U_{\text {wave }}^{\max }$ is obtained by substituting in (2.21) expression for calculating the wave number:

$$
U_{\text {wave }}^{\max }=\frac{\pi H_{\text {wave }}}{T_{\text {wave }} \operatorname{sh}\left(\frac{2 \pi Z_{w}}{L_{\text {wave }}}\right)} .
$$

The length, height and period of the wave are unknown quantities in equation (2.22). For shallow water bodies, the ratio $Z_{w} / L_{\text {wave }}<1 / 25$ is fair. Therefore, the height and period of the wind wave for the conditions of "shallow water" is found from the expressions (Shore protection..., 1984):

$$
H_{\text {wave }}=0.283 \frac{\left(U_{z=10}^{\text {wind }}\right)^{2}}{g} \operatorname{th}(\xi) \operatorname{th}\left(\frac{0.00565 \cdot \sqrt{\frac{g F_{\text {wind }}}{\left(U_{z=10}^{\text {wind }}\right)^{2}}}}{\operatorname{th}(\xi)}\right) \text {, }
$$




$$
T_{\text {wave }}=7.54 \frac{U_{z=10}^{\text {wind }}}{g} \operatorname{th}(\zeta) \operatorname{th}\left(\frac{0.0379 \cdot \sqrt[3]{\frac{g F_{\text {wind }}}{\left(U_{z=10}^{\text {wind }}\right)^{2}}}}{\operatorname{th}(\zeta)}\right) \text {, }
$$

where

$$
\begin{gathered}
\xi=0.53\left(\frac{g Z_{w}}{\left(U_{z=10}^{\text {wind }}\right)^{2}}\right)^{3 / 4}, \\
\zeta=0.833\left(\frac{g Z_{w}}{\left(U_{z=10}^{\text {wind }}\right)^{2}}\right)^{3 / 8},
\end{gathered}
$$

where $g$ - acceleration of gravity, $\mathrm{m} / \mathrm{s}^{2} ; F_{\text {wind }}$ - length of wind acceleration (m); $U_{z=10}^{\text {wind }}$ wind speed at a height of $10 \mathrm{~m}$ above the surface of the water $(\mathrm{m} / \mathrm{s})$. The height of the wave in this calculation is expressed in meters, and the wave period in seconds.

For the calculation, we will use the approximation from (Shore protection..., 1984):

$$
L_{\text {wave }} \approx \frac{g \cdot T_{\text {wave }}^{2}}{2 \pi} \sqrt{\operatorname{th}\left(\left(\frac{2 \pi}{T_{\text {wave }}}\right)^{2} \frac{Z_{w}}{g}\right)} .
$$

It was shown that the maximum error of approximation (2.27) can reach $5 \%$ (Shore protection..., 1984). The maximum error in the computations $L_{\text {wave }}$ takes place when the ratio $\left(2 \pi Z_{w}\right) / L_{\text {wave }}$ is about 1.0 .

The expression for calculating the coefficient of wave friction for an uneven (rough) bottom can be written in a general form (Stanev et al., 2009):

$$
f_{\text {wave }}^{\text {rough_bed }}=\alpha_{w}^{\prime}\left(\frac{A_{\text {wave }}}{k_{s}}\right)^{-\beta_{w}^{\prime}},
$$

where $\alpha_{w}^{\prime}$ and $\beta_{w}^{\prime}$ are empirical coefficients; $A_{\text {wave }}$ is wave amplitude (m); $k_{s}$ is characteristic roughness scale $(\mathrm{m}),\left(k_{s}=2.5 D_{50}\right)$. Thus, the ratio $A_{\text {wave }} / k_{s}$ determines the relative roughness of the bottom. In the calculations, as the first approximation, the following values of the empirical coefficients $\alpha_{w}^{\prime}$ and $\beta_{w}^{\prime}$ can be used (Stanev et al., 2009): $\alpha_{w}^{\prime}=0.237$ and $\beta_{w}^{\prime}=0.52$. However, for specific conditions of a particular water body at the stage of parametric adjustment of the model, the values of these coefficients will need to be clarified.

Taking into account relation (2.22), the amplitude of the wind wave for the "shallow water" conditions is calculated from the following equation: 


$$
A_{\text {wave }}=\frac{H_{\text {wave }}}{2 \operatorname{sh}\left(\frac{2 \pi Z_{w}}{L_{\text {wave }}}\right)} .
$$

The values of height and wavelength are calculated from equations (2.23) and (2.27).

In the modeling practice, other ratios are used to calculate the coefficient of wave friction for an uneven (rough) bottom. They can be written in a general form:

$$
f_{\text {wave }}^{\text {rough bed }}=\exp \left(\alpha_{w}^{\prime \prime}\left(\frac{A_{\text {wave }}}{k_{s}}\right)^{-\beta_{w}^{\prime \prime}}-\gamma_{w}^{\prime \prime}\right),
$$

where $\alpha_{w}^{\prime \prime}, \beta_{w}^{\prime \prime}, \gamma_{w}^{\prime \prime}$ are empirical coefficients. For example, when calculating the values $f_{\text {wave }}^{\text {rough bed }}$, the following values $\left(\alpha_{w}^{\prime \prime}=5.5, \beta_{w}^{\prime \prime}=0.2, \gamma_{w}^{\prime \prime}=6.3\right)$ were obtained for the Baltic Sea conditions (Jönsson, 2005) and $\left(\alpha_{w}^{\prime \prime}=5.213 \alpha_{w}^{\prime \prime}=5.213 \alpha_{w}^{\prime \prime}=5.213\right.$ $\left.\alpha_{w}^{\prime \prime}=5.213 \alpha_{w}^{\prime \prime}=5.213 \alpha_{w}^{\prime \prime}=5.213, \beta_{w}^{\prime \prime}=0.194, \gamma_{w}^{\prime \prime}=5.977\right)$ for the CAEDYM model (Hipsey et al., 2006).

Since there are no universal computational dependencies for computation of $f_{\text {wave }}^{\text {rough }}{ }^{\text {bed }}$, the use of equations (2.28) and (2.30) should be provided for the model.

If the bottom is smooth, then in this case $A_{\text {wave }} / k_{s} \rightarrow \infty$, and the value of the coefficient of wave friction $f_{\text {wave }}$ will depend only on the regimes of water flow (laminar, turbulent or intermediate). In some cases, the intermediate regime is not considered (Stanev et al., 2009).

The expression for calculating the coefficient of wave friction for a smooth bottom can be written in the general form:

$$
f_{\text {wave }}^{\text {smooth_bed }}=M_{w}\left(R e_{w}\right)^{-N_{w}},
$$

where $M_{w}$ and $N_{w}$ are empirical coefficients; $R e_{w}$ - the Reynolds number for the wave motion of water, it is calculated from equation

$$
\operatorname{Re}_{w}=\frac{U_{\text {wave }}^{\max } A_{\text {wave }}}{v_{w}\left(T_{w}, S\right)},
$$

where $v_{w}\left(T_{w}, S\right)$ - coefficient of kinematic viscosity of water, $\mathrm{m}^{2} / \mathrm{sec}$, depending on it $T_{w}$ and $S_{w}$.

In a number of studies for the Baltic Sea, the calculation of the values $f_{\text {wave }}^{\text {smooth bed }}$ for a smooth bottom was carried out for the corresponding flow regime (Jönsson, 2005; Nielsen, 1992):

- if $\operatorname{Re}_{w} \leq 3.0 \times 10^{5}$ (laminar flow regime), then $M_{W}=2.0, N_{W}=0.5$ and then

$$
f_{\text {wave }}^{\text {smoth } \text { bed }}=2.0 / \sqrt{R e_{w}} \text {; }
$$


- if $3.0 \times 10^{5}<R e_{w}<1.0 \times 10^{6}$ (intermediate flow regime), then a linear approximation of the dependence of the coefficient $f_{\text {wave }}^{\text {smooth }}$ bed on the number $R e_{w}$ was used:

$$
f_{\text {wave }}^{\text {smooth_bed }}=3.34 \cdot 10^{-3}+1.05 \cdot 10^{-9} \operatorname{Re}_{w} ;
$$

- if $R e_{w} \geq 1.0 \times 10^{6}$ (turbulent flow regime), then $M_{w}=0.024, N_{w}=0.123$, and

$$
\text { then } f_{\text {wave }}^{\text {smoth bed }}=0.024 R e_{w}^{-0.123} \text {. }
$$

Since there are no universal dependencies for computation of values $f_{\text {wave }}^{\text {smooth bed }}$ (as for $f_{\text {wave }}^{\text {rough bed }}$ ), in the SM-model and its software implementation it is necessary to envisage the use of different methods for estimating the values of $f_{\text {wave }}^{\text {smoth bed }}$ and their possible refinement at the stage of parametric adjustment of the model.

The value of the coefficient of kinematic viscosity $v_{w}\left(T_{w}, S\right)$, in $\mathrm{m}^{2} / \mathrm{s}$, in formula (2.32) is calculated as a function of $v_{w}\left(T_{w}, S\right)$ and $S_{w}$ through the dynamic viscosity $\mu_{w}\left(T_{w}, S\right)$

$$
v_{w}\left(T_{w}, S\right)=\frac{\mu_{w}\left(T_{w}, S\right)}{\rho_{w}\left(T_{w}, S\right)} .
$$

The changes $S_{w}$ and pressures, unlike $T_{w}$, have a negligible effect on the changes in the values $\mu_{w}\left(T_{w}, S\right)$ (Neumann, Pierson, 1966), and instead of $\mu_{w}\left(T_{w}, S\right)$ in the formula (2.36), one can use the value $\mu_{w}\left(T_{w}, 0\right)$ without significant loss of accuracy. Thus, the calculation of $v_{w}\left(T_{w}, S\right)$ is carried out according to the following formula:

$$
v_{w}\left(T_{w}, S\right)=\frac{\mu_{w}\left(T_{w}, 0\right)}{\rho_{w}\left(T_{w}, S\right)} .
$$

To calculate the density of water, the formula (2.15) is used. Values of dynamic viscosity, in $\mathrm{kg} /(\mathrm{m} \times \mathrm{sec})$, are calculated depending on the absolute value $T_{w}\left(T_{w a}\right)$, $T_{w a}=T_{w}+273.15$ according to (Reid et al., 1987):

$$
\mu_{w}\left(T_{w}, 0\right)=10^{-3} \exp \left(-24.71+4.209 \cdot 10^{3} T_{w a}^{-1}+4.527 \cdot 10^{-2} T_{w a}-3.376 \cdot 10^{-5} T_{w a}^{2}\right) .
$$

To estimate the coefficient of horizontal turbulent exchange $K_{T}$ and the horizontal turbulent diffusion coefficient $\left(A_{\eta}\right)_{n}$ for the size fraction $n$, we used the well-known Smagorinsky parametrization (Ryzhin, 1986; Klevanny, Smirnova, 2009; Matishov et al., 2009; Klevanny et al., 2001; Smagorinsky, 1963):

$$
\left(K_{T} ;\left(A_{\eta}\right)_{n}\right)=\alpha\left((\Delta s)_{x}(\Delta s)_{y}\right) \sqrt{2\left(\frac{\partial U}{\partial x}\right)^{2}+\left(\frac{\partial U}{\partial y}+\frac{\partial V}{\partial x}\right)^{2}+2\left(\frac{\partial V}{\partial y}\right)^{2}}
$$


where $(\Delta s)_{x},(\Delta s)_{y}$ - are the grid steps for the spatial coordinates $O X$ and $O Y$, respectively; coefficient $\alpha=0.25-1.0$ in the calculation of $K_{T}$ values and $\alpha=0.1-0.3$ in the calculation of $\left(A_{\eta}\right)_{n}$ values. To calculate the values of the spatial derivatives $\partial U / \partial x, \partial U / \partial y, \partial V / \partial x, \partial V / \partial y$, the central difference approximation was applied.

As follows from formulas (2.10) and (2.11), the SM sedimentation and the stirring up of the bottom sediment will only develop if the tangential stress at the bottom of the water body $\tau_{\text {bottom }}$ is either less $\tau_{C_{n}}^{\text {crit sed }}$ or greater $\tau_{C_{n}}^{\text {crit_resusp }}$, respectively. Critical values of $\tau_{C_{n}}^{\text {crit_sed }}$ and $\tau_{C_{n}}^{\text {crit_resusp }}$ vary within fairly wide limits and should be selected according to the calibration results of the models used to study sediment transport processes in lakes, coastal zones of the seas and sea bays. Existing studies and modeling experience show that the values of $\tau_{C_{n}}^{\text {crit sed }}$ vary in the range $0.0-0.18 \mathrm{~N} / \mathrm{m}^{2}$ (N is a force in Newton) and the values of $\tau_{C_{n}}^{\text {crit resusp }}$ are $0.009-0.25 \mathrm{~N} / \mathrm{m}^{2}$ (Chao et al., 2008; Hamilton, Mitchell, 1996; Lou et al., 2000; Mehta, Partheniades, 1975; Ziegler, Nisbet, 1995).

We estimate the value of $\tau_{\text {bottom }}^{\text {curr }}$ approximately from (2.17). In dredging areas, the depth is usually $10-30 \mathrm{~m}$, so the contribution of this particular term in the equation (2.12) in the calculation $\tau_{\text {bottom }}$ will be decisive. Since the average height $Z_{0}$ of the roughness protrusions of the bottom is $3.5 \times 10^{-5} \mathrm{~m}$, the average depth in the work area is $20 \mathrm{~m}$, the water density is $1000 \mathrm{~kg} / \mathrm{m}^{3}$ and the flow velocity is $0.1 \mathrm{~m} / \mathrm{sec}$, we obtain the value of the resistance coefficient $C_{D}$ :

$$
C_{D}=0.16\left(1+\ln \left(\frac{Z_{0}}{Z_{w}}\right)\right)^{-2}=0.16\left(1+\ln \left(\frac{3.5 \cdot 10^{-5}}{20.0}\right)\right)^{-2}=0.0071,
$$

and the value of the tangential stress at the bottom, caused by the movement of water -

$$
\tau_{\text {bottom }}^{\text {curr }}=\rho_{w} C_{D}\left(U^{\text {curr }}\right)^{2}=0.0071 \cdot 10^{3} \cdot(0.1)^{2} \approx 0.071 \mathrm{~N} / \mathrm{m}^{2} .
$$

To assess the impact of dredging on the state of the environment, as well as the role of SM in biogeochemical processes in aquatic ecosystems, it is sometimes important to take into account the flocculation effect (Lisitsyn, 1994; Mikkelsen, Pejrup, 2000; Hill, 1998; Smith, Friedrichs, 2011; Winterwerp, 2002). The results of observations show that a fraction of the vertical mass flow of SM can occur to the share of micro- and macrofloccules (sometimes up to 50-80 \%) (Smith, Friedrichs, 2011). An increase in either size (flocculation) or particle density leads to an increase in the rate of precipitation. As a result, the time of turbidity spot existence decreases and the concentration of SM in water decreases, as well as the distance covered by the turbidity spot under the influence of advective transport. 
The settling velocity of particles is determined by the balance of gravitational forces, buoyancy effects and medium resistance. These forces depend both on the properties of the fluid (its density, viscosity) and on the properties of the particles (their density, size, shape, degree of porosity). According to the Stokes law (valid only for small Reynolds numbers $\left(\left(\operatorname{Re}_{p}\right)_{n}=\left(\left(W_{s}\right)_{n} \cdot D_{n}\right) / \nu_{w}, n=\overline{1, N}\right)$ and spherical particles), the settling velocity of particles is determined by the equation:

$$
\left(W_{s}\right)_{n}=\frac{\left(\left(\rho_{s}\right)_{n}-\rho_{w}\right) g D_{n}^{2}}{18 \mu_{w}}, n=\overline{1, N},
$$

where $D_{n}$ is the characteristic particle diameter for the $n$-th fraction; $g$-acceleration of gravity; $\left(\rho_{s}\right)_{n}$ - density of particles of suspension for the $n$-th fraction; $\rho_{w}-$ density of water; $\mu_{w}$ - dynamic viscosity of water. In many studies it was noted that for large particles that have a high deposition rate, application of formula (2.40) is illegal (Raudkivi, 1998; Schlichting, Gersten, 2000; Soulsby, 1997; Ten Brinke, 1994; Winterwerp, 1998; 2002). Therefore, a modification of the Stokes formula is required in order that it can be used not only for small but also for large Reynolds numbers.

In natural waters, two main groups of floccula are distinguished according to their characteristic sizes: micro- and macrofloccules (Eisma, 1986). Microflocculess have sizes up to 125 microns, and macroflocculles are larger aggregates with maximum flocculus sizes up to 3-4 $\mathrm{mm}$. Microfloccules usually consist of mineral particles, as well as organic substances of different nature and chemical composition. Macrofloccules are formed by aggregation of microfloccules in an aqueous environment.

The process of flocculation is a complex physicochemical process, depending on a variety of factors (Lisitsyn, 1994; Winterwerp, 1998, 2002). For natural waters, the impact of turbulent exchange is of primary importance, which in a certain range of its intensity leads to an increase in the frequency of collisions of particles, as a result of which the rate of formation of floccules also increases. However, with considerable turbulence, the reverse process (the destruction of floccules) is often observed. In highly eutrophic (highly productive) waters, the rate of flocculation can be affected by biological factors, in particular, metabolic excretions of organisms (as example, mucus formation) that envelop particles of SM and glue them into larger particles (Ayukai, Wolanski, 1997; Eisma, 1986; Fugate, Friedrichs, 2003; Van der Lee, 2000). Thus, it can be concluded that, other things being equal to physical conditions and sufficiently long intervals of time, with increasing biological activity of natural waters, the rate of flocculation can also increase and, as a consequence, the particle deposition rate will be higher (Smith, Friedrichs, 2011).

In most studies on the influence of turbulent exchange on the settling velocity of $\mathrm{SM}$, ratios have been obtained that contain a large number of empirical coefficients, the 
values of which, as a rule, are unknown. Therefore, such calculated dependencies are of little use for practical use. It is necessary to apply low-parameter relations and models that allow experimental verification.

Let us introduce the turbulence energy dissipation parameter $G$ (Winterwerp, 1998, 2002):

$$
G=\sqrt{\varepsilon / \nu_{w}}=v_{w} / \lambda_{0}^{2},
$$

where $\lambda_{0}$ is the Kolmogorov scale for turbulence; $\varepsilon$ - the average dissipation rate of turbulent kinetic energy per the unit of mass. Typical values $\lambda_{0}$ for estuary zones are $10^{2}-10^{3}$ microns (depending on the depth and speed of water flow). For the calculation $G$, the following formula is applied (Manning, 2004):

$$
G=\sqrt{u_{*}^{3} /\left(k_{w} v_{w} z\right)},
$$

in which $u_{*}$ is the dynamic speed due to both the flow of water and wave motion; $k_{w}-$ the von Karman' constant; $z$ - is the distance from the bottom.

An empirical dependence was obtained in (Van Leussen, 1994), which makes it possible to calculate the sedimentation rate of suspended particles from the turbulent exchange characteristic, in terms of the turbulent energy dissipation parameter $G$ :

$$
\left(W_{s}\right)_{n}=\left(W_{s, 0}\right)_{n} \frac{1+a G}{1+b G^{2}}, n=\overline{1, N},
$$

where $\left(W_{s}\right)_{n}$ is the actual sedimentation rate of particles of each size fraction of SM in the presence of turbulence; $\left(W_{s, 0}\right)_{n}$ - settling rate at a value $G=0 ; a, b$ - are empirical constants. The settling rate $\left(W_{s, 0}\right)_{n}-$ is an important parameter in calculating the concentration of SM in water. The value of $\left(W_{s, 0}\right)_{n}$ can be calculated from the equation (Amoundry, 2008):

$$
\left(W_{s, 0}\right)_{n}=\sqrt{\frac{4\left(\left(\rho_{s}\right)_{n} / \rho_{w}-1\right) g D_{n}}{3\left(C_{D}^{s}\right)_{n}}}, n=\overline{1, N},
$$

where $\left(C_{D}^{s}\right)_{n}$ is the coefficient of resistance for spherical particles for each size fraction of SM, depending on the Reynolds number $\left(R e_{p}\right)_{n}$. In a number of cases, the approximate average sedimentation rate of $\mathrm{SM}\left(W_{s, 0}\right)_{n}$ is calculated in a simplified manner, using only data on the granulometric composition of the transported sediments (Methodical guidelines..., 2003).

There are two most common approximations that are used in calculating the drag coefficient $\left(C_{D}^{s}\right)_{n}, n=\overline{1, N}$ for particles of spherical shape (Graf, 1971, Raudkivi, 1998):

$$
\left(C_{D}^{s}\right)_{n}=\frac{24}{\left(\operatorname{Re}_{p}\right)_{n}}\left(1+0.15\left(\operatorname{Re}_{p}\right)_{n}^{0.687}\right),
$$




$$
\left(C_{D}^{s}\right)_{n}=\frac{24}{\left(\operatorname{Re}_{p}\right)_{n}}\left(1+\frac{3}{16}\left(R e_{p}\right)_{n}\right) .
$$

The relation (2.45) is applicable for $\left(R e_{p}\right)_{n}<800$, and the relation (2.46) is for $\left(R e_{p}\right)_{n} \leq 2.0$.

There is another empirical dependence for calculating $\left(W_{s, 0}\right)_{n}$ (Soulsby, 1997):

$$
\left(W_{s, 0}\right)_{n}=\frac{v_{w}}{D_{n}}\left(\sqrt{10.36^{2}+1.049\left(D_{*}\right)_{n}^{3}}-10.36\right), n=\overline{1, N},
$$

where $\left(D_{*}\right)_{n}=\sqrt[3]{g\left(\rho_{s}\right)_{n} /\left(\left(\rho_{w}-1\right) v_{w}^{2}\right)} D_{n}$. The formula (2.47) was obtained in (Soulsby, 1997) on the basis of experiments on precipitation of sand particles. It does not take into account the influence of form and permeability of particles (degree of its porosity) on the deposition rate. It is established that its application consistent with the data of field measurements for a wide range of Reynolds number values $\left(R e_{p}\right)_{n}$. At small values of $\left(R e_{p}\right)_{n}$ the equation (2.47) becomes Stokes' formula (2.40), and for more high values $\left(R e_{p}\right)_{n}$ it becomes close to the approximation (2.44) at the condition that the resistance coefficient is calculated from the ratio (2.45).

In flocculation models, floccules are usually considered as self-similar fractal (or fractional-dimensional) particles (Kranenburg, 1994). To obtain the corresponding computational equations, fractal theory is used (Amoundry, 2008; Kranenburg, 1994; Winterwerp, 1998, 2002). It is assumed that the settling velocity of particles is a function of the characteristic size of the floccules (their projective diameter $D$ ) and the density differential $\Delta \rho_{f}$ (or the excess density of the floccula with respect to the water density). Usually in the calculations for simplicity it is assumed that $D=D_{50}$, and typical values of $\Delta \rho_{f}$ due to the flocculation effect vary within $50-300 \mathrm{~kg} / \mathrm{m}^{3}$ (Winterwerp, 1998).

The distribution of aggregated particles by size can be described by a distribution function - just as they do when specifying the initial granulometric composition of SM. In this model, to simplify the problem, the distribution of floccules throughout the possible size spectrum will not be taken into account, and the so-called equilibrium flocculum size $D_{e}$, which is essentially close to the average (median) particle size $\left(D_{50}\right)$ of the SM (depends on the percentage contribution of particles of different type/size ). The formation of aggregated particles with a characteristic size $D_{e}$ depends on the current balance of many forces and environmental factors that determine flocculation and the establishment of a certain dynamic equilibrium between the processes of formation and destruction of floccules. 
It was shown in (Kranenburg, 1994) that $\Delta \rho_{f}$ is possible to relate to the initial characteristic diameter of suspended particles before the beginning of the flocculation process, as well as to the fractal dimension of the particles, by the following equation:

$$
\Delta \rho_{f}=\rho_{f}-\rho_{w} \sim\left(\rho_{s}-\rho_{w}\right)\left(\frac{D_{p}}{D}\right)^{3-n_{f}},
$$

where $\rho_{f}$ is the density of the floccules; $\rho_{w}$ is density of water; $\rho_{s}$ is the characteristic density of the suspension, which depends on its granulometric composition and physical characteristics. The fractal dimension $n_{f}$ of the floccules varies from 1.4 to 2.2 (Winterwerp, 1998). For spherical dense particles $n_{f}=3$.

The expression for the calculation of the settling velocity of floccules $\left(W_{s}\right)_{f}$ can be obtained from the balance equation for the gravitational sedimentation of slurry and the drag force $F_{d}$ :

$$
\begin{gathered}
F_{g}=\alpha_{f} \frac{\pi}{6} D^{3} \Delta \rho_{f} g, \\
F_{d}=\beta_{f}\left(C_{D}^{s}\right)_{f} \frac{1}{2} \rho_{w} \frac{\pi}{4} D^{2}\left(W_{s}\right)_{f},
\end{gathered}
$$

where $\alpha_{f}, \beta_{f}$ are empirical coefficients (their values depend on the degree of particle sphericity); $\left(C_{D}^{s}\right)_{f}$ is resistance coefficient for settling floccules. In further calculations, for the approximation of $\left(C_{D}^{s}\right)_{f}$ in the calculations, the equation (2.45) will be used.

To calculate the settling rate of floccules $\left(W_{s}\right)_{f}$ from $(2.48)-(2.50)$, we obtain (Winterwerp, 1998):

$$
\left(W_{s}\right)_{f}=\frac{\alpha_{f}}{18 \beta_{f}} \frac{\left(\rho_{s}-\rho_{w}\right) g}{\mu_{w}} D_{p}^{3-n_{f}} \frac{D^{n_{f}-1}}{1+0.15(\operatorname{Re})_{f}^{0.687}} .
$$

For dense particles of spherical shape $\alpha_{f}=\beta_{f}=1$ and $n_{f}=3$. If then $(R e)_{f}<<1$, then equation (2.51) describes the settling of suspended particles in accordance with the Stokes law (2.40). For particles-floccul $>100 \mu \mathrm{m}$, it can be assumed that $n_{f}=2$ (Winterwerp, 1998). Then it follows from equation (2.51) that $\left(W_{s}\right)_{f} \sim D$.

The use of equation (2.51) is complicated by the fact that for calculations it is necessary to know the characteristic size of floccules $D$. Thus, an additional problem arises: the construction of a model that describes the process of formation and destruction of floccules in a turbulent flow of a liquid and allows one to calculate the rate of change in the size of floccules at different intensities of turbulent exchange in water. 
In (Levich, 1962), by integrating the diffusion equation within a finite volume much larger $\lambda_{0}^{3}$, an expression for the velocity process of particle flocculation in a turbulent flow characterized by the turbulent energy dissipation parameter $G$ :

$$
\frac{d n_{f}}{d t}=-1.5 e_{f} \pi e_{d} G D^{3} n_{s f}^{2}
$$

where $n_{s f}$ is the number of particles (flocculum) per unit volume of fluid; $t$ - time; $e_{f}-$ flocculation efficiency parameter (takes into account that not all collisions of particles will result in the formation of floccules); $e_{d}$ - the parameter of the efficiency of the diffusion process. The parameter $e_{f}$ is a function of the physico-chemical properties of SM and water, as well as the properties of organic compounds that are contained in the SM. Equation (2.52) is used in most studies of the flocculation process presented in the literature.

The relationship between bulk $\phi_{f}$ and mass $c_{f}$ concentrations, as well as between $\phi_{f}$ and the number of aggregated particles $n_{s f}$ per unit volume, is reflected by the equation (Winterwerp, 1998).

$$
\phi_{f}=\left(\frac{\rho_{s}-\rho_{w}}{\rho_{f}-\rho_{w}}\right) \frac{c_{f}}{\rho_{s}}=\theta_{f} n_{f} D^{3},
$$

where $\theta_{f}$ is the particle shape factor. For spherical particles $\theta_{f}=\pi / 6$.

The rate of formation and growth of floccules can be estimated from equations (2.48) and (2.53). If we assume that for a certain period of time $\Delta t$ the initial number of particles $n_{s f}$ per unit volume of water and mass concentration $c_{f}$ are constant values, then we can estimate the value $d n_{s f} / d D$ :

$$
\frac{d n_{s f}}{d D}=-\frac{c_{f} n_{s f}}{\rho_{s} \theta_{f}} D_{p}^{n_{f}-3} D^{-n_{f}-1} .
$$

From (2.53) and (2.54) we obtain that

$$
\frac{d n_{s f}}{d t}=\frac{d n_{s f}}{d D} \frac{d D}{d t}=-\frac{c_{f} n_{s f}}{\rho_{s} \theta_{f}} D_{p}^{n_{f}-3} D^{-n_{f}-1} \frac{d D}{d t} .
$$

Then from (2.52) and (2.55) we find that the rate of formation and growth of the size of floccules at different intensities of turbulent exchange in water can be determined by solving a first-order differential equation:

$$
\frac{d D}{d t}=\frac{3}{2} \frac{e_{f} \pi e_{d}}{\theta_{f} n_{s f}} \frac{c_{f}}{\rho_{s}} G D_{p}^{n_{f}-3} D^{4-n_{f}}=k_{A} c_{f} G D^{4-n_{f}},
$$


where $k_{A}=\frac{3}{2} \frac{e_{f} \pi e_{d}}{\theta_{f} n_{s f}} \frac{1}{\rho_{s}} D_{p}^{n_{f}-3}=k_{A}^{\prime} \frac{D_{p}^{n_{f}-3}}{n_{s f} \rho_{s}}$; and $k_{A}^{\prime}=\frac{3}{2} \frac{e_{f} \pi e_{d}}{\theta_{f}}$ is an empirical parameter. The rate of destruction of floccula, depending on the intensity of turbulent exchange, is described by the following differential equation (Winterwerp, 1998):

$$
\frac{d D}{d t}=-k_{B} G^{q_{f}+1}\left(D-D_{p}\right)^{p_{f}} D^{2 q_{f}+1} .
$$

In (2.57), the values of the empirical parameters $p_{f}, q_{f}$ and $k_{B}$ can be derived from field and/or experimental observations. Thus, equations (2.56) and (2.57) describe the process of formation and destruction of floccules in a turbulent flow of a liquid and allow one to calculate the rate of change of their size for different intensity of turbulent exchange in water. General view of the corresponding flocculation model (Winterwerp, 1998):

$$
\frac{d D}{d t}=k_{A} c_{f} G D^{4-n_{f}}-k_{B} G^{q_{f}+1}\left(D-D_{p}\right)^{p_{f}} D^{2 q_{f}+1} .
$$

To simplify the calculations using equation (2.58) and in accordance with the results from (Winterwerp, 1998), we assume that the average fractal dimension $n_{f}=2$. In this case $p_{f}=1$. In a state close to the dynamic equilibrium, $q_{f}=0.5$ (Winterwerp, 1998). On the basis of these simplifying assumptions, from (2.58) we obtain that

$$
\frac{d D}{d t}=k_{A} c_{f} G D^{2}-k_{B} G^{3 / 2}\left(D-D_{p}\right) D^{2} .
$$

As shown by the estimates obtained from field observations and laboratory experiments, the values are $k_{A} \approx 14.6 \mathrm{~m}^{2} / \mathrm{kg}$, and $k_{B} \approx 14.0 \cdot 10^{3} \mathrm{c}^{1 / 2} / \mathrm{m}^{2}$.

It follows from (2.59) that for small values $D$ the formation of floccules will dominate, and for sufficiently large $D$ - the reverse process of their destruction will dominate. It should also be borne in mind that the direction of a process depends on the current intensity of turbulent exchange. Equation (2.59) can be easily solved analytically on the assumption that for some time interval (usually this is a step in time) the value of mass concentration $c_{f}$ is a constant value.

If the processes of formation and destruction of floccules are in a state of dynamic equilibrium, then $d D / d t=0$ and one can obtain an expression for estimating the equilibrium size of floccules $D_{e}$ :

$$
D_{e}=D_{p}+\frac{k_{A} c_{f}}{k_{B} \sqrt{G}}
$$

Then from (2.51) with the aid of (2.60) we obtain the relation for calculating the equilibrium deposition rate of floccules: 


$$
\left(W_{s}\right)_{f, e}=\frac{\alpha_{f}}{18 \beta_{f}} \frac{\left(\rho_{s}-\rho_{w}\right) g}{\mu_{w}} D_{p}^{3-n_{f}} \frac{\left(D_{p}+\frac{k_{A} c_{f}}{k_{B} \sqrt{G}}\right)^{n_{f}-1}}{1+0.15(R e)_{f}^{0.687}}
$$

Assuming that the mean fractal dimension $n_{f}=2$, from (2.61) we find that

$$
\left(W_{s}\right)_{f, e}=\frac{\alpha_{f}}{18 \beta_{f}} \frac{\left(\rho_{s}-\rho_{w}\right) g}{\mu_{w}} D_{p} \frac{\left(D_{p}+\frac{k_{A} c_{f}}{k_{B} \sqrt{G}}\right)}{1+0.15(\operatorname{Re})_{f}^{0.687}} .
$$

Equation (2.62) makes it possible to calculate the equilibrium rate of floccules deposition depending on a number of properties of water and SM: the initial characteristic diameter $D_{p}$ of suspended particles before the flocculation process begins; intensity of turbulent exchange in water; characteristic suspension density $\rho_{s}$ (depends on its granulometric composition and physical characteristics); the density differential $\Delta \rho=\rho_{s}-\rho_{w}$; dynamic viscosity of water $\mu_{w}$; Reynolds number.

Thus, if the flocculation effect is not considered in modeling the propagation of SM, then formulas (2.43) and (2.44) should be used for calculating the rate of their deposition for each size fraction of SM. The question of whether or not to include in the calculations the effect of flocculation of SM should be addressed separately on the basis of additional field and/or laboratory studies of the physico-chemical properties of bottom sediments. In particular, with their help it is necessary to determine which fractions of the initial composition of SM can potentially be subjected to the process of flocculation. Then, in the simulation for this part of SM, the rate of deposition of floccules will be calculated using formula (2.62), and for each of the remaining size fractions - according to formulas (2.43) and (2.44).

\section{Conclusions}

A mathematical model is developed for studying in the natural conditions the processes of propagation of SM in marine coastal areas and ecosystems of sea bays, lagoons and estuaries of rivers. It can also be used to quantify the formation of spots of additional turbidity of water in dredging and any other works in which some external mechanical effect on bottom sediment is expected. In this case, zones of additional turbidity of water are formed as a result of the formation of SM at the sites of such operations and the subsequent spread of SM along the water area in this and adjacent areas. The developed model calculates various indicators that quantify certain structural and functional features of the state of aquatic ecosystems and their spatial and temporal dynamics, and also reflect the degree of disturbance of the natural state of the marine 
environment as the habitat of aquatic biological resources. Such data should be provided to different monitoring bodies when passing the expertise for the AEEP.

Depending on the task being performed, this model will use additional blocks: a biohydrochemical block of the simulation model of the aquatic ecosystem (for example, as in (Leonov, 2008; Podgornyi, Leonov, 2013a,b) will be required to study the processes of biochemical transformation of SM and DOM. For a simpler task of describing the formation of zones of additional turbidity of water during dredging, it is sufficient to use the model block, the propagation of a conservative SM in water. At the same time, a specific technological scheme of dredging and other works should be taken into account. As a rule, SM is represented by organic and mineral fractions in the aqueous medium, therefore it is necessary to take into account all the most important sources of their intake and correctly mathematically formalize the intraspecific processes of substance transformation (take into account the possible external load on the aquatic environment, wind and hydrodynamic effects on bottom sediment, precipitation processes, and resuspension of bottom sediment, and also flocculation processes). In each case, the significance of the processes is individual and it can be estimated when forming the structure of additional model blocks and based on the results of model calculations.

The proposed numerical model considers the modified system of Saint-Venant's equations (the theory of shallow water) for the description of hydrodynamics and circulation of water streams with given boundary conditions - nonflow (or zero normal component of the average velocity over the depth) on the solid contour, radiation on the liquid boundary and energy in the river sections. As the initial ones, the state of rest (zero values of velocities and level) was used. For the numerical solution of the modified Saint-Venant system of equations, an implicit difference scheme using alternating directions is used.

At the second stage, the equations of advection and turbulent diffusion are considered in modeling the processes of formation and propagation of SM in the coastal region under consideration. Boundary and initial conditions are formulated depending on the features of the water body, the tasks assigned and the availability of observational data. The scheme of numerical integration of the initial system of equations of advection and turbulent diffusion is based on the method of splitting by physical processes and spatial coordinates (includes 4 stages - with successive solution of advection equations, gravitational deposition of SM, turbulent exchange of SM and local processes of sedimentation of SM, from point and other sources).

Examples of formalization of empirical functions that determine the influence of important factors depending on environmental conditions and the dominance of individual processes associated with the redistribution of SM between the water 
environment and bottom sediment are given. A number of parameters can be used to calculate the use of different empirical formulas.

To estimate the coefficients of horizontal turbulent exchange and turbulent diffusion, the Smagorinsky parametrization (where one parameter is tuned) is used. In the calculation of spatial derivatives, the central-difference approximation is applied. To calculate the characteristics of turbulence (for example, the kinetic energy of turbulence and the rate of its dissipation) it is required to solve the corresponding nonlinear system of differential equations. The problem of comparing different models of turbulent exchange and the results of modeling with each other and with the data of field observations remains urgent, and additional studies are required for this.

To assess the impact of dredging on the state of the environment and the role of $\mathrm{SM}$ in biohydochemical processes in aquatic ecosystems of marine coastal areas, in zones of mixing sea and fresh water, flocculation should be taken into account in a number of cases. It is associated with the coalescence of particles of SM and, as a consequence, its rapid precipitation. A relationship is obtained for calculating the sedimentation rate of each size fraction of SM, as well as the equilibrium deposition rate of floccules depending on the properties of water, suspension, and intensity of turbulent exchange. With the obtained relations and the developed mathematical model, comprehensive study is possible with quantitative calculation of the transformation rates and spatio-temporal dynamics of SM in highly productive aquatic ecosystems and also in river-sea interaction zones on the so-called "marginal filters" sections.

\section{Acknowledgments}

The authors are grateful to prof. G. I. Barenblatt (Shirshov Institute of Oceanology of the Russian Academy of Sciences) for a careful reading of the article and valuable comments that were taken into account, if possible.

\section{References}

Afanasyev S.V., Ryzhin S.V., Numerical simulation of horizontal turbulent diffusion in a shallow lake, Vod. Resources, 1986, Vol. 13, No. 1, pp. 87-94.

Amoundry L., A review on coastal sediment transport modeling, Proudman Oceanographic Laboratory, Internal document No. 189, 2008, 44 p.

Arkhipov B.V., Koterov V.N., Kocherova A.S., Solbakov V.V., Khublaryan G.M., Calculating sediment transport in the coastal zone of the sea, Water Resources, 2004, Vol. 31, No. 1, pp. 27-34.

Ayukai T., Wolanski E., Importance of biologically mediated removal of fine sediments from the Fly River plume, Papua New Guinea, Estuarine Coastal Shelf Sci., 1997, Vol. 44, pp. 629-639.

Baklanovskaya V.F., Pal'tsev B.V., Chechel I.I., On boundary-value problems for the system of Saint-Venant equations in the plane, Zh. Calculated. Math.and Math. Fiz., 1979, Vol. 19, No. 3, pp. 708-725, [In Russian].

Cebeci T., Turbulence models and their application: Effective numerical methods with computer programs. Long Beach, California, Horizons Publishing Inc., 2004, 118 p. 
Chao X., Jia Y., Shields Jr.F.D., Wang S.S.Y., Cooper C.M., Three-dimensional numerical modeling of cohesive sediment transport and wind wave impact in a shallow oxbow lake, Advances in Water Resources, 2008, Vol. 31, No. 7, pp. 1004-1014.

Chubarenko I., Tchepikova I., Modeling of man-made contribution to salinity increase into the Vistula Lagoon (Baltic Sea), Ecol. Modeling, 2001, Vol. 138, pp. 87-100.

Davies, A.M., Lawrence J., Examining the influence of wind and wind wave turbulence on tidal currents, using a three-dimensional hydrodynamic model including wave-current interaction, J. Phys. Oceanogr., 1994, Vol. 24, pp. 2441-2460.

Einstein H.A., Krone R.B., Experiments to determine modes of cohesive sediment transport in salt water, J. Geophys. Res., 1962, Vol. 67, pp. 1451-146.

Eisma D., Flocculation and de-flocculation of suspended matter in estuaries, Neth. J. Sea Res., 1986, Vol. 20 (2/3), pp. 183-199.

Fahmy O., Fassieh K.M., Zaki M.A., A numerical model of the wave-induced currents in the turbulent coastal zone, ISRN Civil Engineering, 2013, Vol. 2013, Article ID 904180, pp. 1-7. http://dx.doi.org/10.1155/2013/904180.

Fugate D., Friedrichs C.T., Controls on suspended aggregate size in partially mixed estuaries, Estuarine Coastal Shelf Sci., 2003, Vol. 58, pp. 389-404.

Glenn S.M., Grant W.D., A suspended sediment stratification correction for combined waves and current flows, J. Geophys. Res., 1987, Vol. 92, (C8), pp. 8244-8264.

Graf W.H., Hydraulics of sediment transport, New York, McGraw-Hill, 1971, 513 p.

Grant W.D., Madsen O.S., Combined wave and current interaction with a rough bottom, $J$. Geophys. Res., 1979, Vol. 84 (C4), pp. 1797-1808.

Hamilton D.P., Mitchell S.F., An empirical model for sediment resuspension in shallow lakes, Hydrobiologia, 1996, Vol. 317, pp. 209-220.

Hipsey M.R., Romero J.R., Antenucci J.P., Hamilton D., Computational aquatic ecosystem dynamics model: CAEDYM, v.2.3, Science manual, University of Western Australia: Centre for water research, 2006, $102 \mathrm{p}$.

Jönsson A., Model studies of surface waves and sediment resuspension in the Baltic sea, Linköping, Sweden: Linköping University, 2005, 55 p.

Jonsson I.G., Wave boundary layers and friction factors, Proceedings of the $10^{\text {th }}$ International conference on coastal engineering, Tokyo, Japan, ASCE, 1966, pp. 127-148.

Kester D. R., Comparison of recent seawater freezing point data, J. Geophys. Res., 1974, Vol. 79, pp. 4555-4556.

Klevanny K.A., Gubareva V.P., Mostamandy M.S.W., Ozerova L.B., Water level forecasts for the Eastern Gulf of Finland, Bull. of the Maritime Institute, Gdansk, 2001, Vol. 28, No. 2, pp. 71-87.

Klevanny K.A., Smirnova E.V., Use of the CARDINAL software for solving hydraulic problems, Zhurn, University of Water Communications, 2009, Issue 1, pp. 153-162, [In Russian].

Kranenburg C., The fractal structure of cohesive sediment aggregates, Estuarine Coastal Shelf Sci., 1994, Vol. 39, pp. 451-460.

Lai Y.G., Two-dimensional depth-averaged flow modelling with an unstructured hybrid mesh, $J$. Hydraul. Eng., 2010, Vol. 136, pp. 12-23.

Leonov A.V., Modeling of natural processes on the basis of the imitational hydroecological model of transformation of compounds C, N, P, Si. Yuzhno-Sakhalinsk, Sakh State University, 2008, 168 p., [In Russian].

Levich V.G., Physicochemical hydrodynamics, Englewood Cliffs: Prentice Hall, 1962, 700 p.

Lisitsyn A.P., Marginal filter of the oceans, Oceanology, 1994, Vol. 34, No. 5, pp. 735-747, [In Russian].

Lisitsyn A.P., Barenblatt G.I., Hydrodynamics and sedimentation, Moskva, Nauka, 1983, 232 p., [In Russian].

Lou J., Schwab D.J., Beletsky D., Hawley N., A model of sediment resuspension and transport dynamics in southern Lake Michigan, J. Geophys. Res., 2000, Vol. 105, pp. 6591-6610.

Luettich R.A., Harleman D.R.F., Somlyody L., Dynamic behavior of suspended sediment concentrations in a shallow lake perturbed by episodic wind events, Limnol. Oceanogr., 
1990, Vol. 35, pp. 1050-1067.

Maciejewska A., Pempkowiak J., DOC and POC in the water column of the southern Baltic. Part I. Evaluation of factors influencing sources, distribution and concentration dynamics of organic matter, Oceanologia, 2014, Vol. 56, pp. 523-548.

Maciejewska A., Pempkowiak J., DOC and POC in the water column of the southern Baltic. Part II - Evaluation of factors affecting organic matter concentrations using multivariate statistical methods, Oceanologia, 2015, Vol. 57, pp. 168-176.

Manning A.J., The development of new algorithms to parameterize the mass settling flux of flocculated estuarine sediments, Defra Project FD1905. Report TR 145, Rev. 2.0, HR Wallingford, 2004, $48 \mathrm{p}$.

Marchuk G.I., Splitting methods, Moscow: Nauka, 1988, 264 p., [In Russian].

Marchuk G.I., Dymnikov V.P., Zalesny V.B., Mathematical models in geophysical hydrodynamics and numerical methods for their implementation, Leningrad: Gidrometeoizdat, 1987, 296 p., [In Russian].

Matishov G.G., Makarevich P.R., Jenyuk S.L., Marine oil and gas development and rational nature management on the shelf, Rostov-on-Don: YNC Publishing House, 2009, 500 p., [In Russian].

Mehta A.J., Partheniades E., An investigation of the depositional properties of flocculated fine sediment, J. Hydraul. Res., 1975, Vol. 13, pp. 361-381.

Methodical guidelines for calculating the distribution of turbidity zones during dredging and dumping in the Navy. Moscow: MO RF, 2003, 80 p., [In Russian].

MIKE 21 \& MIKE 3 Flow Model FM. Hydrodynamic and Transport Module, Scientific Documentation, Hørsholm, Denmark: DHI, 2012, 50 p.

Mikkelsen O.A., Pejrup M., In situ particle size spectra and density of particle aggregates in a dredging plume, Mar. Geol., 2000, Vol. 170, pp. 443-459.

Milligan T.G., Hill P.S., A laboratory assessment of the relative importance of turbulence, particle composition, and concentration in limiting maximal floc size and settling behavior, J. Sea Res., 1998, Vol. 39, pp. 227-241.

Molchanov M., Eremina T.R., Neelov I.A. Modeling of suspended matter transport in the Neva Bay and the Eastern part of the Gulf of Finland, Proceedings of the $2^{\text {th }}$ International Conference (school) on Dynamics of Coastal Zone of Non-Tidal Seas, Baltiysk (Kaliningrad Oblast), 26-30 June 2010 / Ed. by B. Chubarenko, Kaliningrad: Terra Baltica, 2010, pp. 207-211.

Neumann G., Pierson W.J., Principles of Physical Oceanography. Prentice-Hall, Englewood Cliffs., NJ, 1966, 545 p.

Neumeier U., Ferrarin C., Amos C.L., Umgiesser G., Li M.Z., SEDTRANS05: An improved sediment-transport model for continental shelves and coastal waters with a new algorithm for cohesive sediments, Computers and Geosciences, 2008, Vol. 34, pp. 1223-1242.

Nielsen P., Coastal bottom boundary layers and sediment transport, Advanced series on ocean engineering, 4. Singapore: World Scientific, 1992, 324 p.

Partheniades E., Erosion and deposition of cohesive soils, J. Hydraul. Div. ASCE., 1965, Vol. 91, (HY1), pp. 105-139.

Podgornyi K.A., Mathematical modeling of freshwater ecosystems of non-stratified reservoirs (algorithms and numerical methods), Rybinsk: Publishing house of the Rybinsk Printing House, 2003, 328 p., [In Russian].

Podgornyi K.A., Leonov A.V., The use of a spatially heterogeneous simulation model for studying biotransformation processes of nitrogen and phosphorus compounds and the dynamics of oxygen dissolved in water in the ecosystem of Neva Bay, the Gulf of Finland: 1. Model description, Water Resources, 2013a, Vol. 40, No. 2, pp. 170-180.

Podgornyi K.A., Leonov A.V., The use of a spatially heterogeneous simulation model for studying biotransformation processes of nitrogen and phosphorus compounds and the dynamics of oxygen dissolved in water in the ecosystem of Neva Bay, the Gulf of Finland: 2. Input data for calculations, modeling results, and their analysis, Water Resources, 2013b, Vol. 40, No. 3, pp. 254-270. 


\section{K.A. Podgornyi, A.V. Leonov}

Raudkivi A.J., Loose boundary hydraulics, Taylor \& Francis, London, 1998, 538 p.

Reid R.C., Prausnitz J.M., Poling B.E., The Properties of Gases and Liquids, $4^{\mathrm{tn}}$ ed. New York: McGraw-Hill Book Company, 1987, 741 p.

Rodi $W$., Turbulence models and their application in hydraulics: a state of the art review, Delft, the Netherland: IAHR Publication, 1980, $116 \mathrm{p}$.

Rukhovets L.A., Mathematical modeling of water exchange and distribution of impurities in the Neva Bay, Meteorol. and hydrology, 1982, No. 7, pp. 78-87, [In Russian].

Ryabchenko V.A., Rumyantsev V.A., Konoplev V.N. et al., Evaluation of water quality changes in the Neva Bay after the commissioning of the South-Western treatment facilities of St. Petersburg (according to mathematical modeling), Izv. Russian Geographical Society, 2006, Vol. 138, No. 5, pp. 48-57, [In Russian].

Ryanzhin S.V., Terzhevik A.Yu., Afanasyev S.V., Hydrodynamic regime and conditions of accumulation of bottom sediments, Preservation of a natural ecosystem of a reservoir in the urbanized landscape. Leningrad: Nauka, 1984, pp. 83-92, [In Russian].

Samarskii A.A, Vabishchevich P.N., Additive schemes for problems of mathematical physics. Moscow: Nauka, 1999a, 320 p., [In Russian].

Samarskii A.A., Vabishchevich P.N., Numerical methods for solving convection-diffusion problems. Moscow: Editorial URSS, 1999b, 248 p., [In Russian].

Schlichting H., Gersten K., Boundary-layer theory. Springer, Berlin, 2000, 811 p.

Shore protection manual. U.S. Army engineer waterways experimental station, Coastal engineering research centre, V. I, 4 edition, PO Box 631, Vicksburg, Mississippi 39180, $1984,652 \mathrm{p}$.

Signell R.P., Beardsley R.C., Graber H.C., Capotondi A., Effect of wave-current interaction on wind-driven circulation in narrow, shallow embayments, J. Geophys. Res., 1990, Vol. 95, pp. 9671-9678.

Smagorinsky J., General circulation experiments with the primitive equations. I. Basic experiment, Monthly Weather Review, 1963, Vol. 91, pp. 99-164.

Smith S.J., Friedrichs C.T., Size and settling velocities of cohesive flocs and suspended sediment aggregates in a trailing suction hopper dredge plume, Cont. Shelf Res., 2011, Vol. 31, pp. $550-563$.

Soulsby R.L., Dynamics of marine sands: a manual for practical applications, HR Wallingford, Thomas Telford Publications, 1997, $253 \mathrm{p}$.

Stanev E.V., Dobrynin M., Pleskachevsky A., et al., Bed shear stress in the southern North Sea as an important driver for suspended sediment dynamics, Ocean Dynamics, 2009, Vol. 59, pp. $183-194$.

Teeter A.M., Johnson B.H., Berger C. et al., Hydrodynamic and sediment transport modeling with emphasis on shallow-water, vegetated area (lakes, reservoirs, estuaries and lagoons), Hydrobiologia, 2001, Vol. 444, pp. 1-23.

Ten Brinke W.B.M., Settling velocities of mud aggregates in the Oosterschelde tidal basin (The Netherlands), determined by a submersible video system, Estuarine Coastal Shelf Sci., 1994, Vol. 39, pp. 549-564.

Van der Lee W.T.B., Temporal variation of floc size and settling velocity in the Dollard estuary, Cont. Shelf Res., 2000, Vol. 20, pp. 1495-1511.

Van Leussen $W$., Estuarine macroflocs and their role in fine-grained sediment transport. $\mathrm{PhD}$ Thesis, University of Utrecht., 1994, 488 p.

Winterwerp J.C., A simple model for turbulence induced flocculation of cohesive sediment, $J$. Hydraul. Res., 1998, Vol. 36, pp. 309-326.

Winterwerp J.C., On the flocculation and settling velocity of estuarine mud, Cont. Shelf Res., 2002, Vol. 22, pp. 1339-1360.

Ziegler C.K., Nisbet B.S., Long-term simulation of fine-grained sediment transport in large reservoir, J. Hydraul. Eng., 1995, Vol. 121, pp. 773-781. 


\title{
МОДЕЛИРОВАНИЕ ПРОЦЕССОВ РАСПРОСТРАНЕНИЯ ВЗВЕШЕННОГО ВЕЩЕСТВА В МОРСКИХ ПРИБРЕЖНЫХ АКВАТОРИЯХ: 1. ОПИСАНИЕ ВВ-МОДЕЛИ
}

\author{
К. А. Подгорный ${ }^{1}$, А. В. Леонов ${ }^{2}$ \\ ${ }^{1}$ Атлантический НИИ рыбного хозяйства и океанографии, \\ 236000, г. Калининград, ул. Дм. Донского, д. 5, \\ e-mail:kapborok@mail.ru \\ ${ }^{2}$ Институт океанологии им. П.П. Ширшова РАН, 117997, Москва, \\ Нахимовский проспект, д. 36, е-mail: leonov@ocean.ru, \\ Статья поступила в редакцию 05.09.2017, одобрена к печати 25.12.2017
}

\begin{abstract}
Рассмотрена методика разработки математической модели для изучения распределения концентраций взвешенного вещества в прибрежных морских акваториях. Эта модель оценивает последствия дноуглубительных работ (нарушений естественного состояния морской среды для биоресурсов), она воспроизводит образование взвешенного вещества и его последующий перенос в водной среде в мелководных морских заливах и морских прибрежных акваториях. Эта задача решается в два основных этапа: сначала проводится численное интегрирование системы уравнений гидродинамики (уравнений теории «мелкой воды») и определяются значения средних по глубине составляющих скорости течения; и на втором этапе - интегрируется система уравнений турбулентной диффузии, учитываются процессы седиментации взвешенного вещества, взмучивания донных отложений, поступления взвеси из распределенных точечных источников, их перераспределения в водной среде и накопления остаточных количеств на дне.
\end{abstract}

Ключевые слова: уравнения теории мелкой воды; система уравнений адвекции и турбулентной диффузии; начальные и граничные условия

\section{Литература}

Архипов Б.В., Котеров В.Н., Кочерова А.С., Солбаков В.В., Хубларян Г.М. Расчет распространения взвешенных веществ в прибрежной области моря // Водные ресурсы. 2004. Т. 31. № 1. С. 31- 39.

Афанасьев C.В., Рянжин С.В. Численное моделирование горизонтальной турбулентной диффузии в мелком озере // Вод.ресурсы. 1986. Т. 13. № 1. С. 87-94.

Баклановская В.Ф., Пальцев Б.В., Чечель И.И. О краевых задачах для системы уравнений Сен-Венана на плоскости // Журн. вычисл. матем. и матем. физ. 1979. Т. 19. № 3. С. 708-725.

Клеванный К.А., Смирнова Е.В. Использование программного комплекса CARDINAL для решения задач гидравлики // Журн. Университета Водных коммуникаций. 2009. Вып. 1. С. 153-162.

Леонов A.B. Моделирование природных процессов на основе имитационной гидроэкологической модели трансформации соединений $\mathrm{C}, \mathrm{N}, \mathrm{P}, \mathrm{Si}$. ЮжноСахалинск: СахГУ, 2008. 168 с.

Лисицын А.П. Маргинальный фильтр океанов // Океанология. 1994. Т. 34. № 5. С. 735747.

Лисицын А.П., Баренблатт Г.И. Гидродинамика и осадкообразование. М.: Наука, 1983. 


\section{K.A. Podgornyi, A.V. Leonov}

$232 \mathrm{c}$.

Марчук Г.И. Методы расщепления. М.: Наука, 1988. 264 с.

Марчук Г.И., Дымников В.П., Залесный В.Б. Математические модели в геофизической гидродинамике и численные методы их реализации. Л.: Гидрометеоиздат, 1987. $296 \mathrm{c}$.

Матишов Г.Г., Макаревич П.Р., Дженюк С.Л. и др. Морские нефтегазовые разработки и рациональное природопользование на шельфе. Ростов-на-Дону: Изд-во ЮНЦ, 2009. $500 \mathrm{c}$.

Методические указания по расчету распространения зон мутности при дноуглублении и дампинге на акваториях ВМФ. М.: МО РФ, 2003. 80 с.

Подгорный K.A. Математическое моделирование пресноводных экосистем нестратифицированных водоемов (алгоритмы и численные методы). Рыбинск: Издво ОАО “Рыбинский Дом печати”, 2003. 328 с.

Подгорный К.A., Леонов A.B. Использование пространственно-неоднородной имитационной модели для изучения процессов биотрансформации соединений азота, фосфора и динамики растворенного в воде кислорода в экосистеме Невской губы Финского залива. 1. Описание модели // Водные ресурсы. 2013а. Т. 40. № 2. С. 179-191.

Подгорный К.A., Леонов А.В. Использование пространственно-неоднородной имитационной модели для изучения процессов биотрансформации соединений азота, фосфора и динамики растворенного в воде кислорода в экосистеме Невской губы Финского залива. 2. Входные данные для расчетов, результаты моделирования и их анализ // Водные ресурсы. 2013б. Т. 40. № 3. С. 240-258.

Руховеи Л.А. Математическое моделирование водообмена и распространения примесей в Невской губе // Метеорол. и гидрология. 1982. № 7. С. 78-87.

Рябченко B.A., Румянцев В.А., Коноплев В.Н. и др. Оценка изменения качества воды Невской губы после введения в эксплуатацию юго-западных очистных сооружений Санкт-Петерурга (по данным математического моделирования) // Изв. Русского Географического Общества. 2006. Т. 138. Вып. 5. С. 48-57.

Рянжин С.В., Тержевик А.Ю., Афанасьев С.В. и др. Гидродинамический режим и условия накопления донных осадков // Сохранение природной экосистемы водоема в урбанизированном ландшафте. Л.: Наука, 1984. С. 83-92.

Самарский А.А., Вабищевич П.Н. Аддитивные схемы для задач математической физики. М.: Наука, 1999а. 320 с.

Самарский А.А., Вабищевич П.Н. Численные методы решения задач конвекциидиффузии. М.: Эдиториал УРСС, 1999б. 248 с.

Amoundry L.A review on coastal sediment transport modelling // Proudman Oceanographic Laboratory. Internal document No. 189. 2008. 44 p.

Ayukai T., Wolanski E. Importance of biologically mediated removal of fine sediments from the Fly River plume, Papua New Guinea // Estuarine Coastal Shelf Sci. 1997. Vol. 44. P. 629-639.

Cebeci T. Turbulence models and their application: Efficient numerical methods with computer programs. Long Beach, California: Horizons Publishing Inc., 2004. 118 p.

Chao X., Jia Y., Shields Jr. F.D., et al. Three-dimensional modeling of cohesive sediment transport and wind wave impact in a shallow oxbow lake // Adv. Water Res. 2008. Vol. 31. P. 1004-1014.

Chubarenko I., Tchepikova I. Modelling of man-made contribution to salinity increase into the Vistula Lagoon (Baltic Sea) // Ecol. Modelling. 2001. Vol. 138. P. 87-100.

Davies A.M., Lawrence J. Examining the influence of wind and wind wave turbulence on tidal currents, using a three-dimensional hydrodynamic model including wave-current interaction // J. Phys. Oceanogr. 1994. Vol. 24. P. 2441-2460.

Einstein H.A., Krone R.B. Experiments to determine modes of cohesive sediment transport in salt water // J. Geophys. Res. 1962.Vol. 67. P. 1451-1461. 
Eisma D. Flocculation and de-flocculation of suspended matter in estuaries // Neth. J. Sea Res. 1986. Vol. 20 (2/3). P. 183-199.

Fahmy O., Fassieh K.M., Zaki M.A. A numerical model of the wave-induced currents in the turbulent coastal zone // ISRN Civil Engineering. 2013. Vol. 2013. P. 1-7.

Fugate D., Friedrichs C.T. Controls on suspended aggregate size in partially mixed estuaries // Estuarine Coastal Shelf Sci. 2003. Vol. 58. P. 389-404.

Glenn S.M., Grant W.D. A suspended sediment stratification correction for combined waves and current flows // J. Geophys. Res. 1987. Vol. 92 (C8). P. 8244-8264.

Graf W.H. Hydraulics of sediment transport. New York: McGraw-Hill, 1971. 513 p.

Grant W.D., Madsen O.S. Combined wave and current interaction with a rough bottom // J. Geophys. Res. 1979. Vol. 84 (C4). P. 1797-1808.

Hamilton D.P., Mitchell S.F. An empirical model for sediment resuspension in shallow lakes // Hydrobiologia. 1996. Vol. 317. P. 209-220.

Hipsey M.R., Romero J.R., Antenucci J.P., Hamilton D. Computational aquatic ecosystem dynamics model: CAEDYM, v.2.3, Science manual. University of Western Australia: Centre for water research, 2006. $102 \mathrm{p}$.

Jönsson A. Model studies of surface waves and sediment resuspension in the Baltic sea. Linköping, Sweden: Linköping University, 2005. 55 p.

Jonsson I.G. Wave boundary layers and friction factors // Proceedings of the $10^{\text {nd }}$ International conference on coastal engineering. Tokyo, Japan, ASCE, 1966. P. 127-148.

Kester, D. R. Comparison of recent seawater freezing point data // J. Geophys. Res. 1974. Vol. 79. P. 4555-4556.

Klevanny K.A., Gubareva V.P., Mostamandy M.S.W., Ozerova L.B. Water level forecasts for the Eastern Gulf of Finland // Bull. of the Maritime Institute, Gdansk. 2001. Vol. 28. No. 2. P. 71-87.

Kranenburg C. The fractal structure of cohesive sediment aggregates // Estuarine Coastal Shelf Sci. 1994. Vol. 39. P. 451-460.

Lai Y.G. Two-dimensional depth-averaged flow modelling with an unstructured hybrid mesh // J. Hydraul. Eng. 2010. Vol. 136. P. 12-23.

Levich V.G. Physicochemical hydrodynamics. Englewood Cliffs: Prentice Hall, 1962. 700 p.

Lou J., Schwab D.J., Beletsky D., Hawley N.A model of sediment resuspension and transport dynamics in southern Lake Michigan // J. Geophys. Res. 2000. Vol. 105. P. 6591-6610.

Luettich R.A., Harleman D.R.F., Somlyody L. Dynamic behavior of suspended sediment concentrations in a shallow lake perturbed by episodic wind events // Limnol. Oceanogr. 1990. Vol. 35. P. 1050-1067.

Manning A.J. The development of new algorithms to parameterize the mass settling flux of flocculated estuarine sediments. // Defra Project FD1905. Report TR 145. Rev. 2.0. HR Wallingford, 2004. $48 \mathrm{p}$.

Maciejewska A., Pempkowiak J. DOC and POC in the water column of the southern Baltic. Part I. Evaluation of factors influencing sources, distribution and concentration dynamics of organic matter // Oceanologia. 2014. Vol. 56. P. 523-548.

Maciejewska A., Pempkowiak J. DOC and POC in the water column of the southern Baltic. Part II - Evaluation of factors affecting organic matter concentrations using multivariate statistical methods // Oceanologia. 2015. Vol. 57. P. 168-176.

Mehta A.J., Partheniades E. An investigation of the depositional properties of flocculated fine sediment // J. Hydraul. Res. 1975. Vol. 13. P. 361-381.

MIKE 21 \& MIKE 3 Flow Model FM. Hydrodynamic and Transport Module. Scientific Documentation. Hørsholm, Denmark: DHI, 2012. 50 p.

Mikkelsen O.A., Pejrup M. In situ particle size spectra and density of particle aggregates in a dredging plume // Mar. Geol. 2000. Vol. 170. P. 443-459. 


\section{K.A. Podgornyi, A.V. Leonov}

Milligan T.G., Hill P.S.A laboratory assessment of the relative importance of turbulence, particle composition, and concentration in limiting maximal floc size and settling behavior // J. Sea Res. 1998. Vol. 39. P. 227-241.

Molchanov M., Eremina T.R., Neelov I.A. Modeling of suspended matter transport in the Neva Bay and the Eastern part of the Gulf of Finland // Proceedings of the $2^{\text {nd }}$ International Conference (school) on Dynamics of Coastal Zone of Non-Tidal Seas. Baltiysk (Kaliningrad Oblast), 26-30 June 2010 / Ed. by B. Chubarenko. Kaliningrad: Terra Baltica, 2010. P. 207-211.

Neumann G., Pierson W.J. Principles of Physical Oceanography. Prentice-Hall, Englewood Cliffs, NJ, 1966. 545 p.

Neumeier U., Ferrarin C., Amos C.L., Umgiesser G., Li M.Z. SEDTRANS05: An improved sediment-transport model for continental shelves and coastal waters with a new algorithm for cohesive sediments // Computers and Geosciences. 2008. Vol. 34. P. 1223-1242.

Nielsen P. Coastal bottom boundary layers and sediment transport. Advanced series on ocean engineering, 4. Singapore: World Scientific, 1992. 324 p.

Partheniades E. Erosion and deposition of cohesive soils // J. Hydraul. Div. ASCE. 1965. Vol. 91 (HY1). P. 105-139.

Raudkivi A.J. Loose boundary hydraulics. Taylor \& Francis, London, 1998. 538 p.

Reid R.C., Prausnitz J.M., Poling B.E. The Properties of Gases and Liquids. $4^{\text {th }}$ ed. New York: McGraw-Hill Book Company, 1987. $741 \mathrm{p}$.

Rodi $W$. Turbulence models and their application in hydraulics: a state of the art review. Delft, the Netherland: IAHR Publication, 1980. $116 \mathrm{p}$.

Schlichting H., Gersten K. Boundary-layer theory. Springer, Berlin, 2000. 811 p.

Shore protection manual. U.S. Army engineer waterways experimental station. Coastal engineering research centre. V. I, $4^{\text {th }}$ edition. PO Box 631, Vicksburg, Mississippi 39180 , 1984. $652 \mathrm{p}$.

Signell R.P., Beardsley R.C., Graber H.C., Capotondi A. Effect of wave-current interaction on wind-driven circulation in narrow, shallow embayments // J. Geophys. Res. 1990. Vol. 95. P. 9671-9678.

Smagorinsky J. General circulation experiments with the primitive equations. I. Basic experiment // Monthly Weather Review. 1963. Vol. 91. P. 99-164.

Smith S.J., Friedrichs C.T. Size and settling velocities of cohesive flocs and suspended sediment aggregates in a trailing suction hopper dredge plume // Cont. Shelf Res. 2011. Vol. 31. P. 550-563.

Soulsby R.L. Dynamics of marine sands: a manual for practical applications. HR Wallingford, Thomas Telford Publications, 1997. 253 p.

Stanev E.V., Dobrynin M., Pleskachevsky A., et al. Bed shear stress in the southern North Sea as an important driver for suspended sediment dynamics // Ocean Dynamics. 2009. Vol. 59. P. $183-194$.

Teeter A.M., Johnson B.H., Berger C. et al. Hydrodynamic and sediment transport modeling with emphasis on shallow-water, vegetated area (lakes, reservoirs, estuaries and lagoons) // Hydrobiologia. 2001. Vol. 444. P. 1-23.

Ten Brinke W.B.M. Settling velocities of mud aggregates in the Oosterschelde tidal basin (The Netherlands), determined by a submersible video system // Estuarine Coastal Shelf Sci. 1994. Vol. 39. P. 549-564.

Van der Lee W.T.B. Temporal variation of floc size and settling velocity in the Dollard estuary // Cont. Shelf Res. 2000. Vol. 20. P. 1495-1511.

Van Leussen $W$. Estuarine macroflocs and their role in fine-grained sediment transport. $\mathrm{PhD}$ Thesis, University of Utrecht. 1994. 488 p.

Winterwerp J.C. A simple model for turbulence induced flocculation of cohesive sediment // J. 
Океанологические исследования 2017. Том 45. № 1.С. 109-141

Hydraul. Res. 1998. Vol. 36. P. 309-326.

Winterwerp J.C. On the flocculation and settling velocity of estuarine mud // Cont. Shelf Res. 2002. Vol. 22. P. 1339-1360.

Ziegler C.K., Nisbet B.S. Long-term simulation of fine-grained sediment transport in large reservoir // J. Hydraul. Eng. 1995. Vol. 121. P. 773-781. 